\title{
The sole LSm complex in Cyanidioschyzon merolae associates with pre-mRNA splicing and mRNA degradation factors
}

\author{
KIRSTEN A. REIMER, ${ }^{1,9}$ MARTHA R. STARK, ${ }^{1}$ LISBETH-CAROLINA AGUILAR, ${ }^{2}$ SIERRA R. STARK, ${ }^{1}$ \\ ROBERT D. BURKE, ${ }^{3}$ JACK MOORE, ${ }^{4}$ RICHARD P. FAHLMAN, $^{4,5}$ CALVIN K. YIP, $^{6}$ HARUKO KUROIWA, ${ }^{7}$ \\ MARLENE OEFFINGER, ${ }^{2,8}$ and STEPHEN D. RADER ${ }^{1}$ \\ ${ }^{1}$ Department of Chemistry, University of Northern British Columbia, Prince George, BC V2N 4Z9, Canada \\ ${ }^{2}$ Laboratory of RNP Biochemistry, Institut de Recherches Cliniques de Montréal (IRCM), Faculty of Medicine, McGill University, Montreal, \\ QC H3A 0G4, Canada \\ ${ }^{3}$ Department of Biochemistry and Microbiology, University of Victoria, Victoria, BC, V8W 3P6, Canada \\ ${ }^{4}$ Department of Biochemistry, University of Alberta, Edmonton, Alberta T6G 2H7, Canada \\ ${ }^{5}$ Department of Oncology, University of Alberta, Edmonton, Alberta T6G 2H7, Canada \\ ${ }^{6}$ Department of Biochemistry and Molecular Biology, The University of British Columbia, Vancouver, BC V6T 1Z3, Canada \\ ${ }^{7}$ Kuroiwa Initiative Research Unit, College of Science, Rikkyo University, Toshima, Tokyo 171-8501, Japan \\ ${ }^{8}$ Département de Biochimie, Université de Montréal, Montréal, QC H2W 1R7, Canada
}

\begin{abstract}
Proteins of the Sm and Sm-like (LSm) families, referred to collectively as (L)Sm proteins, are found in all three domains of life and are known to promote a variety of RNA processes such as base-pair formation, unwinding, RNA degradation, and RNA stabilization. In eukaryotes, (L)Sm proteins have been studied, inter alia, for their role in pre-mRNA splicing. In many organisms, the LSm proteins form two distinct complexes, one consisting of LSm1-7 that is involved in mRNA degradation in the cytoplasm, and the other consisting of LSm2-8 that binds spliceosomal U6 snRNA in the nucleus. We recently characterized the splicing proteins from the red alga Cyanidioschyzon merolae and found that it has only seven LSm proteins. The identities of $\mathrm{CmLSm} 2-\mathrm{CmLSm} 7$ were unambiguous, but the seventh protein was similar to LSm1 and LSm8. Here, we use in vitro binding measurements, microscopy, and affinity purification-mass spectrometry to demonstrate a canonical splicing function for the $C$. merolae LSm complex and experimentally validate our bioinformatic predictions of a reduced spliceosome in this organism. Copurification of Pat1 and its associated mRNA degradation proteins with the LSm proteins, along with evidence of a cytoplasmic fraction of $\mathrm{CmLSm}$ complexes, argues that this complex is involved in both splicing and cytoplasmic mRNA degradation. Intriguingly, the Pat1 complex also copurifies with all four snRNAs, suggesting the possibility of a spliceosome-associated pre-mRNA degradation complex in the nucleus.
\end{abstract}

Keywords: Cyanidioschyzon merolae; LSm complex; U6 snRNA; pre-mRNA splicing; mRNA degradation; Pat1

\section{INTRODUCTION}

Nuclear pre-mRNA splicing is the eukaryotic process of removing introns from pre-messenger RNA (Berget et al. 1977; Chow et al. 1977). In the stepwise splicing reaction, $\mathrm{U} 1, \mathrm{U} 2, \mathrm{U} 4, \mathrm{U} 5$, and U6 snRNAs assemble with proteins to form discrete small, nuclear ribonucleoproteins (snRNPs) that assemble on the pre-mRNA and catalyze the splicing reaction (Wahl et al. 2009). In addition to snRNA-specific proteins, four snRNPs (U1, U2, U4, and U5) contain a common

\footnotetext{
${ }^{9}$ Present address: Department of Molecular Biophysics and Biochemistry, Yale University, New Haven, CT 06520, USA

Corresponding author: rader@unbc.ca

Article is online at http://www.rnajournal.org/cgi/doi/10.1261/rna. 058487.116 .
}

heteroheptameric Sm protein complex that binds to the $3^{\prime}$ end of the snRNA (Lerner and Steitz 1979). In contrast, U6 associates with a heteroheptameric complex of Sm-like (LSm) proteins (Séraphin 1995).

(L)Sm proteins form a variety of RNA-binding complexes in Eukaryotes and Archaea (Wilusz and Wilusz 2013). Nine different LSm proteins have been identified in yeast, eight of which form two major complexes: the LSm 2-8 proteins form a complex involved in pre-mRNA splicing (Mayes et al. 1999; Salgado-Garrido et al. 1999), and the LSm 1-7

\footnotetext{
(C) 2017 Reimer et al. This article is distributed exclusively by the RNA Society for the first 12 months after the full-issue publication date (see http://rnajournal.cshlp.org/site/misc/terms.xhtml). After 12 months, it is available under a Creative Commons License (Attribution-NonCommercial 4.0 International), as described at http://creativecommons.org/licenses/ by-nc/4.0/.
} 
proteins form a similar complex involved in mRNA degradation (Tharun et al. 2000). These two distinct complexes share six of the seven subunits (LSm 2-7); however, they have dramatically different roles and cellular localizations (splicing in the nucleus and mRNA degradation in the cytoplasm). The splicing-associated LSm complex binds U6 snRNA (Vidal et al. 1999), whereas the mRNA degradation complex is found to be associated with enzymes recruited for mRNA degradation, namely Pat1, Xrn1, Dhh1, Edc3, Edc4, Scd6, and Dcp1/2 (Bouveret et al. 2000; Franks and LykkeAndersen 2008; Fromm et al. 2012; Cary et al. 2015). In addition, LSm proteins have been found to interact with U8 snRNA in Xenopus (Tomasevic and Peculis 2002) and other small RNAs (Fischer et al. 2010), and have been implicated in pre-tRNA and pre-rRNA processing (Beggs 2005) and telomerase RNA processing (Tang et al. 2012). The presence of LSm and Sm-like proteins in eukarya, archaea, and bacteria (which contain the Sm-motif-containing Hfq complex), as well as their wide variety of functions, indicates that (L)Sm proteins are important in modulating several aspects of RNA and RNP biogenesis.

Recently, we reported a dramatically reduced set of splicing components in the red alga Cyanidioschyzon merolae (Stark et al. 2015), whose genome had been found to contain only 27 introns (Matsuzaki et al. 2004). We proposed that this organism offers a more tractable system for studying the complex process of splicing, as it harbors only 31 proteins predicted to assemble into snRNPs. Furthermore, we found few snRNP biogenesis factors, and a startling absence of the U1 snRNA and U1-associated proteins. Interestingly, we found only seven LSm proteins, in contrast to the eight or more LSm proteins found in other eukaryotes. This suggests that only one LSm complex forms in C. merolae. We were able to unambiguously identify the CmLSm 2-7 subunits by sequence comparison; however, the remaining subunit showed similarity to LSm1 and LSm8. Thus, it was unclear whether the CmLSm complex is involved in splicing or in mRNA degradation.

In order to determine the function of this singular LSm complex, we investigated its association with the U6 snRNA, which would indicate a role in splicing. Here, we show that recombinantly purified C. merolae LSm complex binds $C$. merolae U6 snRNA in vitro. We report that immunoprecipitating the LSm complex copurifies U6 snRNA along with many other splicing proteins from $C$. merolae extract, and that in the reciprocal experiment, U6 snRNA pulldown copurifies the LSm proteins. These data, in combination with the observation of a nuclear fraction of LSm proteins, support a splicing function for the CmLSm complex. Nevertheless, we also observed the Pat1-associated mRNA degradation complex, not only in CmLSm immunoprecipitation, but also in all of the snRNA pull-downs. Together with a clear cytoplasmic fraction of CmLSm proteins, this supports an mRNA degradation function for the CmLSm complex.

\section{RESULTS}

While looking for splicing proteins in C. merolae, we identified $\mathrm{CmLSm}$ proteins $2-7$ as the top hits from human homologs (Fig. 1A). The alignment highlights the conservation of known residues in the Sm motif (Cooper et al. 1995; Séraphin 1995); however, BLAST searches were unable to clearly distinguish whether the remaining protein was LSm1 or LSm8. In order to determine which protein the CmLSm1/8 candidate was most similar to, and therefore which LSm function the $C$. merolae proteins would be implicated in, we aligned the sequence of the $\mathrm{CmLSm} 1 / 8$ candidate with LSm 1 and LSm8 protein sequences from other organisms (Fig. 1B,C). The CmLSm1/8 protein showed greatest similarity to the LSm 1 proteins in terms of sequence conservation. For example, the CmLSm1/8 protein is $29 \%$ identical to Saccharomyces cerevisiae (Sc) LSm1 (Fig. 1B), but only $20 \%$ identical to Sc LSm8 (Fig. 1C). To further test the evolutionary relationship of the C. merolae protein to $\mathrm{LSm} 1$ and $\mathrm{LSm} 8$ proteins, we calculated phylogenetic trees with a variety of homologs, using distantly related proteins as outgroups. In all trees calculated, CmLSm1/8 unambiguously segregated with the LSm1 proteins (Fig. 1D). This suggests that the CmLSm complex is more similar to the cytosolic LSm1-7 complex involved in mRNA degradation, leaving open the question of whether these proteins have any role in premRNA splicing. If the CmLSm complex is not associated with U6 during splicing, however, U6 would be predicted to have no associated proteins (since C. merolae lacks the canonical U6 snRNP protein Prp24 [Stark et al. 2015]). We therefore hypothesized that, even though the composition of the CmLSm complex appeared more similar to the mRNA degradation complex, the CmLSms are nevertheless associated with U6 snRNA.

In order to address the function of the CmLSm complex in vitro, we expressed and reconstituted the recombinant CmLSm complex from Escherischia coli. We generated an expression vector for the seven CmLSm genes using the pQLink-based expression system we previously developed for the yeast LSm complex (Dunn 2014). A peak eluted from a gel filtration column in a volume intermediate to the $158 \mathrm{kDa}$ and $44 \mathrm{kDa}$ size standards, consistent with the predicted complex mass of $92 \mathrm{kDa}$ (Fig. 2A). SDS-PAGE showed bands corresponding to four unique sizes (Fig. 2B). Since several of the CmLSm subunits are close in size, we expect bands to comigrate (see annotations at left, Fig. 2B). Human and yeast LSm complexes form a torus (Zaric et al. 2005; Karaduman et al. 2008), so we analyzed the CmLSm complex by negative stain electron microscopy (EM). Twodimensional analysis revealed that, similar to the human and yeast complexes, the purified CmLSm complex adopts an overall toroidal architecture (Fig. 2C), consistent with its predicted properties. To confirm the composition of the complex, we analyzed the purified sample by mass spectrometry, which showed the presence of all seven expressed 
A $1 \mathrm{CmLsm1/8} \quad 100.08$ $2 \mathrm{CmLsm2} 16.58$ $3 \mathrm{CmLsm3} 21.68$ 4 CmLsm4 23.5 \% 5 CmLsm5 22.38 6 CmLsm6 20.48

consensus $/ 70$ 요

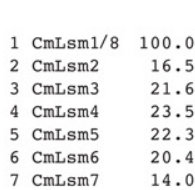

consensus $/ 708$

B

1 Sc LSm1 100.0

2 Sp LSm1 37.48

3 Hs LSm1 35.78

4 At LSm1 29.18

5 Ot LSm1 24.88

$6 \mathrm{Cr}$ LSm1 $30.1 \%$

7 Gs LSm1 $25.6 \%$

8 Cm LSm $1 / 8 \quad 29.08$

consensus/708
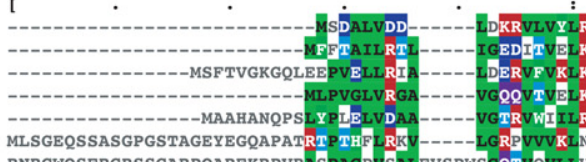

RNRGWOSERGRSSGARPQAREKRPVRASPAGPVSALEVSP

hhpst11cs

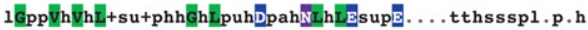

121

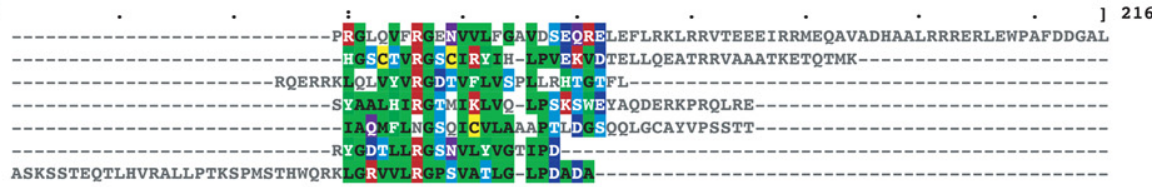

.huthhl $\mathbf{R G s} 1$ hhlu.1Pstphp.............

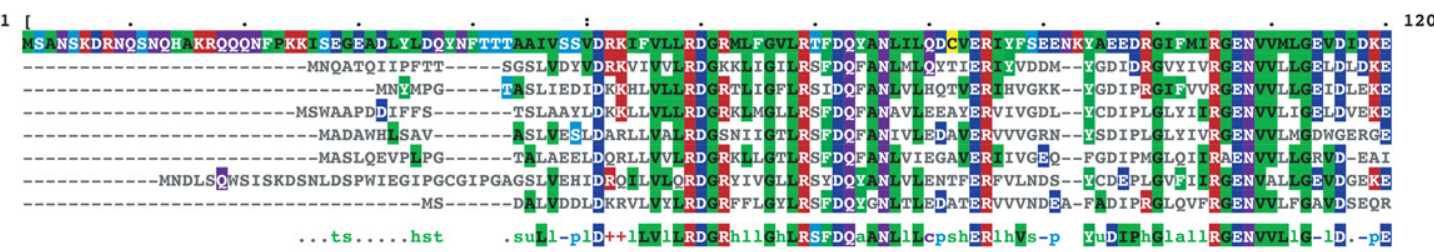

121

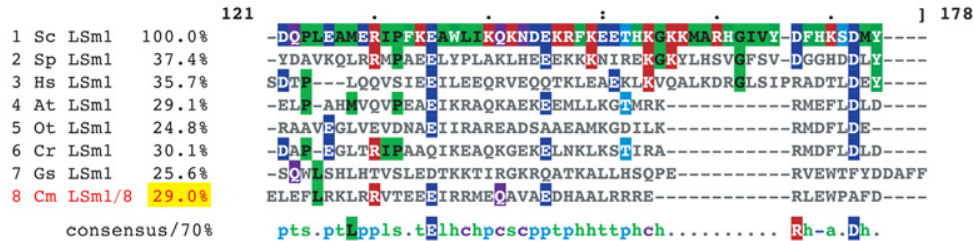

C

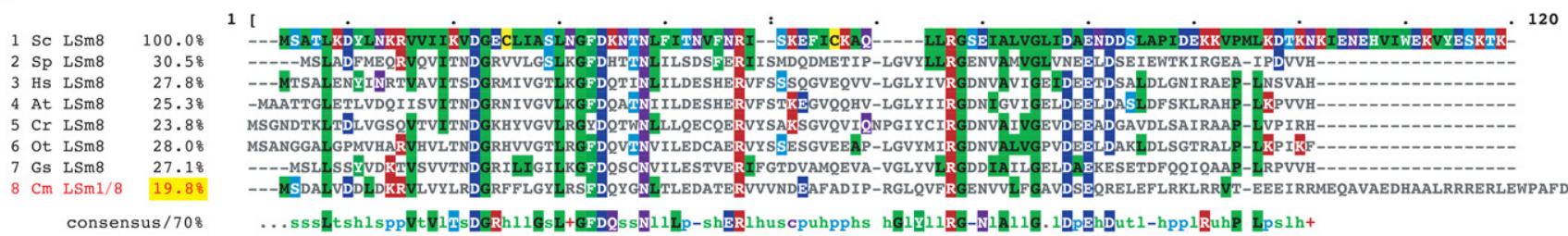

D

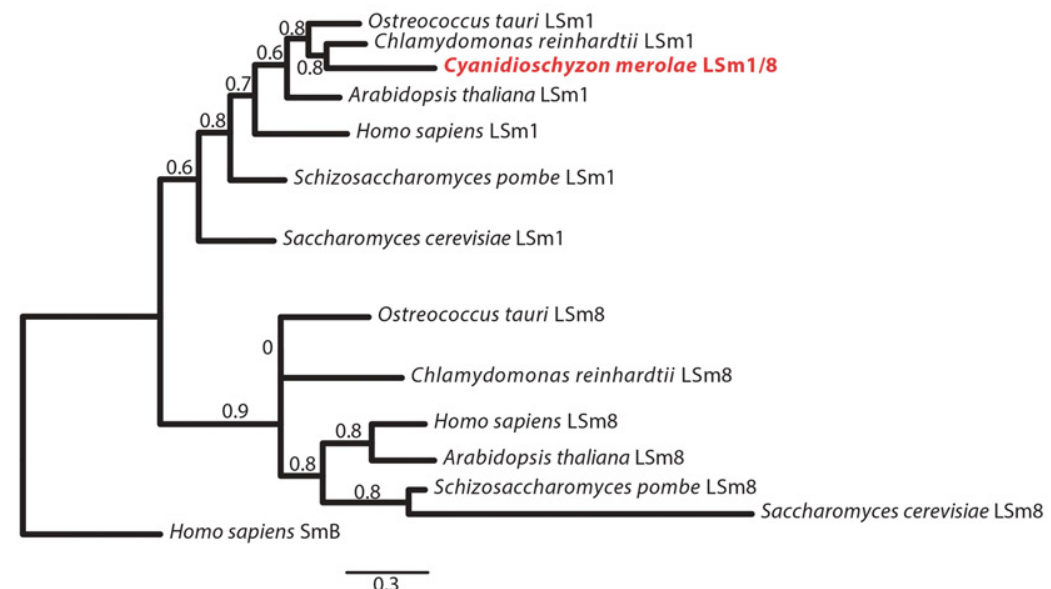

FIGURE 1. The putative CmLSm1/8 protein sequence is most similar to LSm1 proteins. (A) Multiple sequence alignment of $C$. merolae LSm proteins. The LSm7 sequence (XP_005537866.1) begins at amino acid 35. Percent identities are normalized by aligned length. Residues are colored by identity and property. The consensus sequence at a 70\% threshold is shown below, with symbols as defined in MVIEW (Brown et al. 1998). C. merolae LSm1/8 aligned with (B) LSm1 proteins and (C) LSm8 proteins of Saccharomyces cerevisiae (Sc), Schizosaccharomyces pombe (Sp), Homo sapiens (Hs), Arabidopsis thaliana (At), Ostreococcus tauri (Ot), Chlamydomonas reinhardtii (Cr), and Galdieria sulphuraria (Gs), formatted as in A. (D) Phylogenetic tree of LSm1 and LSm8 sequences, showing that CmLSm1/8 clusters within the LSm1 sequences. Branch support values were calculated with PhyML (Guindon et al. 2010), and the scale bar indicates the number of amino acid substitutions per site. 


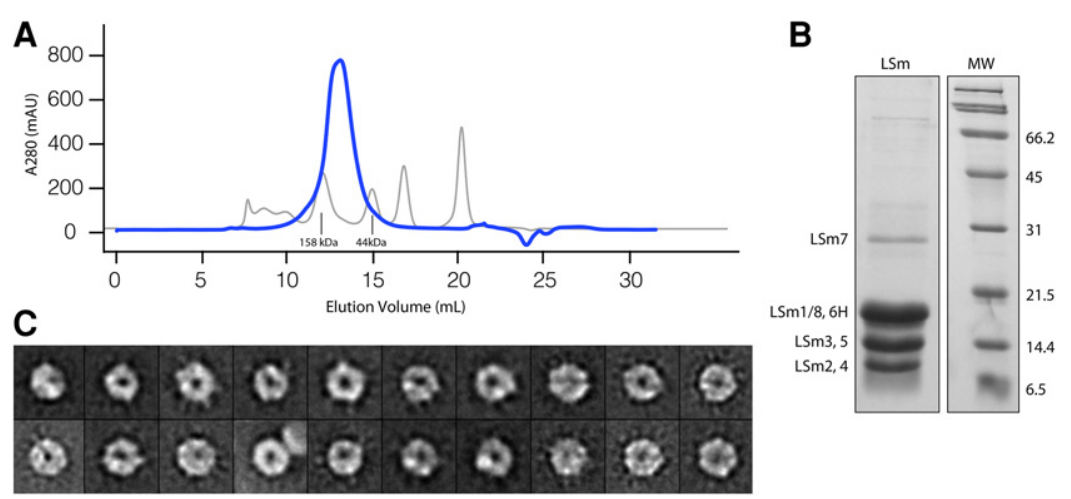

FIGURE 2. The C. merolae LSm proteins associate into a toroidal complex. (A) Gel filtration chromatography of the CmLSm proteins expressed in E. coli. The blue line corresponds to the LSm proteins, while the light gray line shows the elution peaks for gel filtration standards. Molecular masses of the closest standards are below the corresponding peaks. (B) SDS-PAGE analysis of the CmLSm complex. Identity of the LSm proteins is given at left based on mass spectrometric analysis (Supplemental Table S1) $6 \mathrm{H}=\mathrm{Lsm} 6$ with a His tag). (Right) Molecular weight marker sizes in $\mathrm{kDa}$. $(C)$ Representative class averages of $\mathrm{CmLSm}$ complexes by negative stain electron microscopy. Each average image represents $\sim 800$ particles.

proteins (see Supplemental Material). These observations suggested that the CmLSm complex was organized similarly to other LSm complexes.

To test directly the hypothesized interaction between the CmLSm complex and U6 snRNA, we performed electrophoretic mobility shift assays (EMSAs) with the recombinantly purified CmLSm complex and full length, in vitro transcribed U6. High concentrations of CmLSm complex $(>100 \mathrm{nM})$ resulted in a quantitative shift of U6 snRNA from the free-to-bound form as detected by native gel electrophoresis (Fig. 3A). To calculate the dissociation constant $\left(K_{d}\right)$, we plotted the fraction of bound U6 against the concentration of LSm protein and fit the binding data to the Hill equation as described in Materials and Methods (Fig. 3B). The $K_{d}$ for full-length U6 binding the LSm complex was calculated to be $120 \pm 15 \mathrm{nM}$, and the line fit gave a Hill coefficient of $n=1.2 \pm 0.2$. This value is consistent with the LSm complex binding as a single particle, rather than each protein assembling individually onto the RNA.

Previous reports have shown that the $3^{\prime}$ uridine-rich end of U6 is necessary for LSm binding (Achsel et al. 1999). Similarly, cross-links have been observed in S. cerevisiae between the LSm complex and the base of the $3^{\prime}$ stem loop of U6 (Karaduman et al. 2006). Both of these potential binding elements are conserved in the predicted secondary structure of CmU6 (Fig. 3C; Stark et al. 2015). In order to investigate whether these sites are important for LSm binding in C. merolae, we designed two oligonucleotides corresponding to the above-mentioned regions of U6 (ro62, 3' end: Fig. 3C, highlighted region, and ro63, $3^{\prime}$ end+stem: Fig. 3D) and repeated the EMSAs. Increasing concentrations of LSm complex were capable of shifting both oligos from free-to-bound forms (Supplemental Fig. S1). The ro62 oligo gave a $K_{d}$ of 150 $\mathrm{nM}$, and the ro63 gave a $K_{d}$ of $180 \mathrm{nM}$ (Table 1). These values indicate that the $3^{\prime} \mathrm{U}$-rich end is sufficient for LSm binding, as including residues to encompass more of U6 does not substantially increase the binding affinity of the LSm complex. In contrast to some reports (Licht et al. 2008), but consistent with others (Zhou et al. 2014), the similarity of $K_{d}$ values between the oligonucleotides (with $3^{\prime} \mathrm{OH}$ ) and full-length U6 (with a $3^{\prime}$ cyclic phosphate) suggests that a $3^{\prime}$ cyclic phosphate is not an important determinant for LSm binding in C. merolae. These data show that the CmLSm complex binds U6 quantitatively, implying a role for the LSm complex in splicing.

To establish the specificity of the CmLSm complex for U6, we measured the CmLSm complex's binding affinity for a small fragment of U4 snRNA. We did not expect the CmLSm complex to bind this fragment, since it does not contain the canonical uridine-rich LSm binding site. Using an oligo corresponding to the $5^{\prime}$ kink-turn of $C$. merolae U4 (ro52; Fig. 3E), we observed no binding interaction at LSm concentrations up to $10 \mu \mathrm{M}$ (Fig. 3F, lanes 7-11). In contrast, we observed binding between the ro52 oligo and CmSnul3 (Fig. 3 F, lanes 2-6), as demonstrated previously (Black et al. 2016). Together, these results indicate that the C. merolae LSm complex binds specifically, and with high affinity, to U6 snRNA.

In light of these in vitro results, we sought evidence for U6: LSm binding in C. merolae whole-cell extract. We immunoprecipitated the LSm proteins from extract using anti-LSm polyclonal antiserum raised against the recombinant LSm complex (Fig. 4A, lane 2), but not with non-immune serum (lane 3). The immunoprecipitated proteins comigrate with recombinant $\mathrm{CmLSm}$ proteins (lane 1). We extracted RNA from the immunoprecipitated pellet and analyzed the resulting RNA by Northern blotting for all four snRNAs (Fig. 4B). We observed a band of the expected size for U6 in the coimmunoprecipitated RNA (Fig. 4B, lane 5), but not in the nonimmune control (lane 3). By comparing RNA from the supernatant $(\mathrm{S})$ and the immunoprecipitated pellet $(\mathrm{P})$, we found that, on average, $42 \%$ of U6 in extract was precipitated by the anti-LSm antiserum (Table 2; Fig. 4C). Interestingly, when we probed for the other three C. merolae snRNAs, we observed $38 \%$ of total U4, 39\% of U5, and $12 \%$ of U2 in the precipitates. In contrast, the non-immune serum pulled down $2 \%$ of U6, $3 \%$ of U4, $1 \%$ of U5, and $4 \%$ of U2 (Table 2). While copurification of U4, U5, and U6 can be explained by their association in the tri-snRNP, the unexpected copurification of U2 snRNA may be due to cross-reactivity of the LSm antiserum with Sm proteins (MR Stark, unpubl.). These results supported our in vitro experiments by demonstrating an interaction between U6 and the LSm complex in C. merolae extract. The copurification 
A

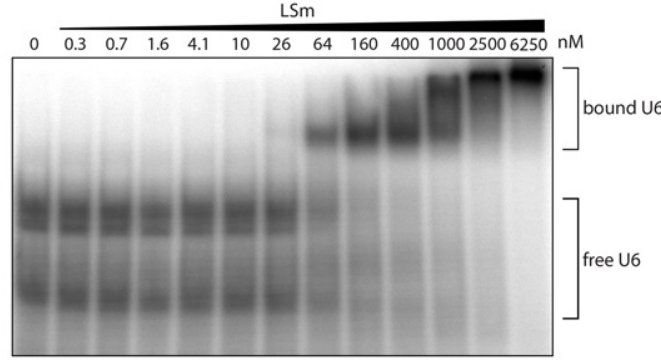

B

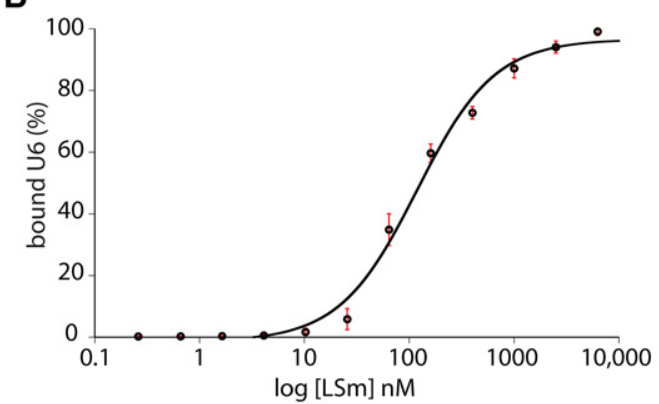

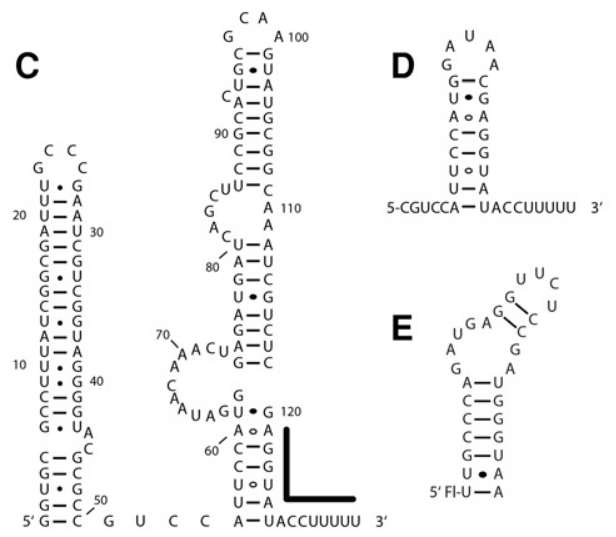

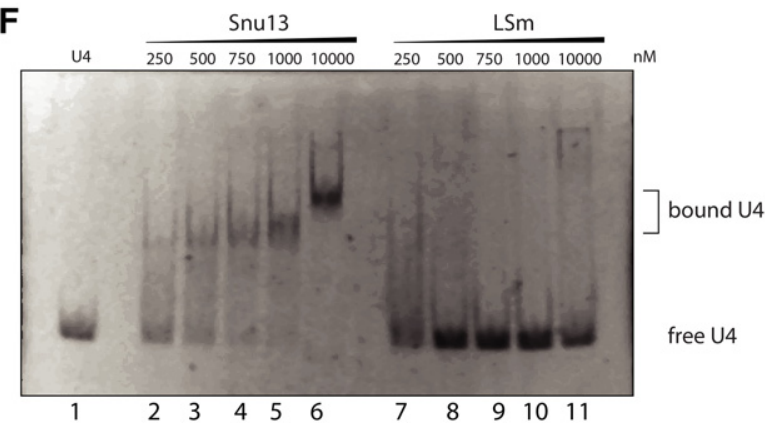

FIGURE 3. The CmLSm complex binds U6 snRNA in vitro. (A) Electrophoretic mobility shift assay with recombinantly purified LSm complex and in vitro transcribed, ${ }^{32} \mathrm{P}$-labeled U6. Protein concentrations are indicated (top) and free U6 is shown in lane 1. (B) U6:LSm binding data (open circles) and line fit (solid line). Error bars are the standard error from three replicates. $(C)$ Predicted secondary structure of $C$. merolae full-length U6 (Stark et al. 2015). The sequence used for the $3^{\prime}$-end oligo (ro62) is highlighted by the dark line. (D) Predicted structure of the $3^{\prime}$ end + stem oligo (ro63) corresponding to the base of the U6 stem. (E) Predicted structure of the U4 oligo (ro52) corresponding to the C. merolae U4 kink-turn. "Fl" denotes the $5^{\prime}$ fluorescein moiety. $(F)$ Fluorescent EMSA with the U4 snRNA oligo. Free U4 oligo is shown in the first lane, with increasing amounts of a known binding partner, CmSnu13, as indicated, and the CmLSm complex at concentrations of 250-10,000 nM.

of U2, U4, and U5 further supports our contention that the $\mathrm{CmLSm}$ proteins are involved in splicing.

To investigate the composition of particle(s) immunoprecipitated with the LSm antiserum, we analyzed copurified proteins by mass spectrometry (IP-MS). We identified 58 proteins that yielded at least two unique peptides and that were more than twofold enriched relative to the IgG control (Table 3, coIP columns). Aside from the LSm complex, we identified 17 splicing proteins previously found in C. merolae (Stark et al. 2015), including six of the seven Sm proteins canonically associated with U2, U4, and U5; U4/U6 snRNP proteins Snu13 and Prp3; U5 proteins Prp8, Brr2, and Snu114; U2 protein Rse1; Sub2 from the A complex; EJC proteins THOC2 and Yral; the splicing regulator Quaking;

TABLE 1. U6 snRNA binding parameters

\begin{tabular}{llcc}
\hline U6 construct & $K_{d}(\mathrm{nM})$ & Relative $K_{d}$ & Hill coefficient \\
\hline Full length & 120 & 1 & $1.2 \pm 0.2$ \\
$3^{\prime}$ end (ro62) & 150 & 1 & $2.2 \pm 0.1$ \\
3' end + stem (ro63) $^{\prime}$ & 180 & 2 & $1.8 \pm 0.2$ \\
Control (ro52) & $>10,000$ & $>100$ & $\mathrm{n} / \mathrm{d}$ \\
\hline
\end{tabular}

and Pab1 (Table 3). In addition, 11 ribosomal and chloroplast proteins, and 12 proteins with other nonsplicing annotations, were identified that we assumed to be contaminants. Notably, 11 of the detected proteins were not annotated in the genome and not previously identified as part of the spliceosome, and therefore could be splicing proteins that were too divergent to detect in our original analysis (Stark et al. 2015). Of these, seven had no significant BLAST hits, but two, CMR356C and CMS485C, appeared to be homologs of Prp4 and Prp31. BLAST searches with CMR356C yielded known Prp4 homologs in five organisms (Table 4), albeit with E-values above the cutoff we used in our original searches (Stark et al. 2015). BLAST searches with CMS485C yielded Prp31, but not always as the top hit, and with relatively poor E-values (Table 4). While sequence alignments of CMR356C (Supplemental Fig. S2) and CMS485C (Supplemental Fig. S3) only confirm the presence of WD and Nop motifs, respectively (Horowitz et al. 1997; Bizarro et al. 2015), and have remarkably low sequence identities to their $S$. cerevisiae homologs of $14 \%$ and $12 \%$, the identification of these proteins as CmPrp4 and CmPrp31 is consistent with their substantial abundance in the list of proteins coimmunoprecipitated with the LSm proteins. 
A
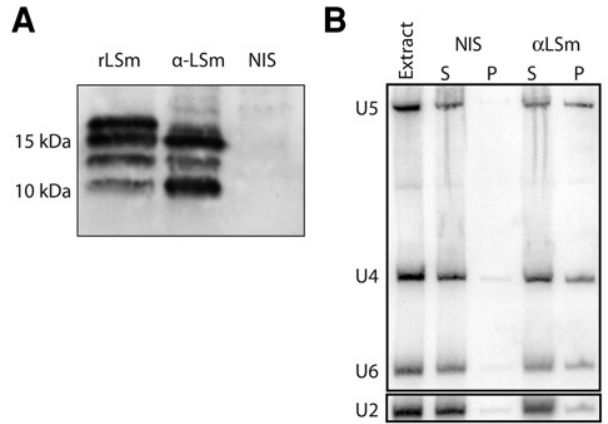

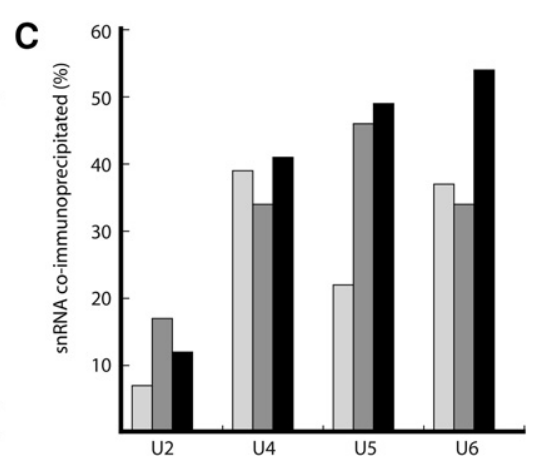

FIGURE 4. U6 snRNA associates with the LSm complex in C. merolae extract. (A) Western blot of CmLSm proteins immunoprecipitated from C. merolae whole-cell extract using anti-CmLSm antibodies. Lane 1, $50 \mathrm{ng}$ recombinantly purified CmLSm protein; lane 2, immunoprecipitate from anti-CmLSm serum; and lane 3, immunoprecipitate from non-immune serum (NIS). Numbers at left indicate position of molecular weight standards. (B) Northern blot of coimmunoprecipitated RNA probed for U5, U4, and U6 (top panel), and U2 (bottom panel). Lane 1, total RNA from C. merolae whole-cell extract; lanes 2-3, supernatant (S) and pellet (P) from control immunoprecipitation with non-immune serum; lanes $4-5$, supernatant $(\mathrm{S})$ and pellet $(\mathrm{P})$ from immunoprecipitation with anti-CmLSm serum. $(C)$ Percentage of U2, U4, U5, and U6 snRNAs coimmunoprecipitated by the anti-CmLSm antiserum $(n=3)$.

One of the annotated, nonsplicing proteins in the IP-MS experiment was Dcp1 (Table 3), which raised the possibility that $\mathrm{CmLSm}$ proteins are associated with mRNA degradation machinery as well as splicing factors. As we had not previously sought mRNA degradation proteins in C. merolae, we performed searches for the known members of this pathway. These searches revealed clear homologs for Dcp2, Xrn1, and Dhh1, the latter having an astounding 65\%-71\% identity with homologs (Table 5). We also found good candidates for Edc4 and Scd6, and confirmed the identity of Dcp1, but we were unable to identify homologs of Pat1 or Edc3. In addition to Dcp1, we were therefore able to identify Xrn1, Edc4, and Scd6 in the coimmunoprecipitated proteins (Table 3). We noticed, however, that CMB102C, annotated only as "hypothetical protein," was the second most highly enriched protein in the IP-MS experiment. PSI-BLAST searches yielded Pat1 homologs, but with high E-values (Table 5). We therefore aligned CMB102C with a number of previously identified Pat1 homologs (Supplemental Fig. S4). The alignments revealed a protein with a comparable length to its homologs, comparable divergence from the S. cerevisiae protein, and conserved topo II binding motifs (Wang et al. 1996).

To further test the possibility that CMB102C could be a Pat1 ortholog, we used the LOMETS homology modeling metaserver (Wu and Zhang 2007) to find proteins with whose three-dimensional structures CMB102C's sequence was consistent. Five of the top 10 results, as ranked by the LOMETS confidence score, corresponded to the C-terminal portion of Pat1 homologs, and the top two had $Z$-scores of 80 , demonstrating high-quality modeling results (Table 6; $\mathrm{Wu}$ and Zhang 2007). Structure-based alignment of CMB102C with Pat1 (Supplemental Fig. S5) was slightly different from sequence-based alignment (Supplemental Fig. S4), although they were generally within 10 amino acids of one another.
Figure 5 shows the fit between the CMB102C model and the Pat1 structure (panel A), demonstrating the overall consistency between the CMB102C sequence and Pat1's three-dimensional fold (Sharif and Conti 2013; Wu et al. 2014). Amino acids predicted to be at the interface between CMB102C and the LSm proteins have similar properties and orientations to those in Patl's interface (Fig. 5B). We have therefore provisionally identified CMB102C as the Pat1 ortholog in $C$. merolae.

Based on these observations, we hypothesized that there are two separate CmLSm complexes, one nuclear splicing complex and one cytoplasmic degradation complex, and that in making whole-cell extract they became mixed, resulting in immunoprecipitation of both.

To test this, we used 2'OMe antisense oligonucleotide pull-downs to investigate whether only splicing proteins would copurify with U6 snRNA. Northern analysis of the pull-down showed that we isolated $~ 70 \%$ of U6 from extract, compared to $<1 \%$ when using a control oligo (Fig. 6 , lanes 8 and 2). In addition, $\sim 50 \%$ of $\mathrm{U} 4$ was isolated, consistent with known base-pairing between C. merolae $\mathrm{U} 4$ and U6 (Stark et al. 2015). Mass spectrometric identification of U6-associated proteins (2'OMe-MS) revealed the LSms, as expected, as well as U4-associated Sm proteins and Prp3, Prp4, and Prp31, supporting the identification of the latter two proteins in the IP-MS experiment (Table 3). We also observed U5-associated proteins Prp8, Brr2, and Snu114, consistent with the probable existence of tri-snRNP in C. merolae, and with the low levels of U5 visible in the Northern blot (Fig. 6 , lane 8 ). We detected a variety of other splicing proteins, including some from the U2 snRNP and various step-specific factors (Table 3). Unexpectedly, we also found all of the mRNA degradation proteins except Dcp1 to be substantially enriched relative to the control.

While the U6-LSm interaction might conceivably reassort during cell lysis and complex purification, resulting in LSmassociated degradation complexes becoming associated with U6, it seemed less likely that this could happen with other snRNAs, particularly U2. We therefore performed pull-

TABLE 2. snRNA coimmunoprecipitation with LSm antibodies

\begin{tabular}{lcccc}
\hline snRNA & $\alpha$ LSm IP (\%) & SEM & NIS IP (\%) & SEM \\
\hline U2 & 12 & 3 & 4 & 0 \\
U4 & 38 & 2 & 3 & 0 \\
U5 & 39 & 9 & 1 & 0 \\
U6 & 42 & 6 & 2 & 1 \\
\hline
\end{tabular}


TABLE 3. MS-MS results

\begin{tabular}{|c|c|c|c|c|c|c|c|c|c|c|}
\hline \multirow[b]{2}{*}{ Particle or step } & \multirow[b]{2}{*}{ Protein } & \multirow{2}{*}{$\begin{array}{l}\mathrm{MW} \\
(\mathrm{kDa})\end{array}$} & \multirow{2}{*}{$\begin{array}{c}\text { Accession } \\
\text { number }\end{array}$} & \multicolumn{2}{|c|}{ colP } & \multicolumn{5}{|c|}{ 2'O-methyl pull-down } \\
\hline & & & & $\lg G$ & $\mathrm{LSm}$ & Control & U6 & U4 & U5 & U2 \\
\hline \multirow[t]{7}{*}{ U6 } & LSm1 & 15 & gi|544218471 & 0 & 144 & 9 & 75 & 25 & 33 & 36 \\
\hline & LSm2 & 11 & gi|544209633 & 0 & 71 & 0 & 25 & 12 & 12 & 11 \\
\hline & LSm3 & 12 & gi|544218259 & 0 & 48 & 7 & 22 & 14 & 12 & 14 \\
\hline & LSm4 & 11 & $\begin{array}{l}\text { gi|544210944 } \\
\text { gi|544218709 }\end{array}$ & 0 & 48 & 4 & 16 & 9 & 10 & 0 \\
\hline & LSm5 & 11 & gi|544215363 & 0 & 18 & 0 & 11 & 2 & 6 & 4 \\
\hline & Lsm6 & 11 & gi|544215335 & 0 & 39 & 0 & 13 & 10 & 7 & 7 \\
\hline & LSm7 & 22 & gi|544215441 & 0 & 67 & 19 & 54 & 32 & 38 & 33 \\
\hline \multirow[t]{7}{*}{$\mathrm{Sm}$} & $\mathrm{SmB}$ & 9 & gi|544212616 & 0 & 7 & 0 & 7 & 3 & 0 & 15 \\
\hline & SmD1 & 15 & gi|544210697 & 0 & 9 & 0 & 23 & 17 & 11 & 45 \\
\hline & SmD2 & 36 & gi|544214527 & 0 & 18 & 0 & 28 & 18 & 13 & 94 \\
\hline & SmD3 & 19 & gi|544213674 & 0 & 19 & 0 & 41 & 21 & 15 & 108 \\
\hline & SmE & 12 & $\begin{array}{l}\text { gi|544211511 } \\
\text { gi|544213736 }\end{array}$ & 0 & 10 & 0 & 15 & 11 & 11 & 60 \\
\hline & SmF & 10 & gi|544215924 & & & 0 & 0 & 3 & 0 & 19 \\
\hline & SmG & 11 & gi|544215110 & 0 & 5 & 0 & 7 & 3 & 0 & 36 \\
\hline \multirow[t]{4}{*}{ U4/U6 } & Prp3 & 59 & gi|544218113 & 0 & 85 & 0 & 97 & 30 & 0 & 8 \\
\hline & Snu13 & 16 & gi|544215625 & 2 & 9 & 7 & 12 & 16 & 15 & 9 \\
\hline & Prp4 & 51 & gi|544216891 & 0 & 33 & 0 & 64 & 25 & 0 & 0 \\
\hline & Prp31 & 41 & gi|544217836 & 0 & 18 & 3 & 40 & 3 & 3 & 2 \\
\hline \multirow[t]{3}{*}{ U5 } & Prp8 & 274 & gi|544211441 & 0 & 5 & 0 & 10 & 16 & 61 & 3 \\
\hline & Brr2 & 205 & gi|544213359 & 0 & 3 & 2 & 17 & 15 & 51 & 12 \\
\hline & Snu114 & 122 & gi|544212916 & 0 & 4 & 0 & 6 & 3 & 51 & 4 \\
\hline \multirow[t]{9}{*}{ U2 } & Prp9 & 60 & gi|544216280 & & & 0 & 4 & 0 & 12 & 269 \\
\hline & Prp11 & 19 & $\begin{array}{l}\text { gi|544211339 } \\
\text { gi|544214213 }\end{array}$ & & & 0 & 0 & 0 & 3 & 73 \\
\hline & Prp21 & 50 & gi|544212559 & & & 0 & 4 & 2 & 6 & 203 \\
\hline & Hsh155 & 104 & gi|544209427 & & & 0 & 9 & 10 & 11 & 397 \\
\hline & Rse1 & 179 & gi|544213209 & 0 & 3 & 9 & 48 & 43 & 17 & 198 \\
\hline & Hsh49 & 14 & gi|544210354 & & & 0 & 0 & 0 & 0 & 100 \\
\hline & Cus1 & 29 & gi|544218405 & & & 0 & 0 & 0 & 0 & 60 \\
\hline & Rds3 & 14 & gi|544217118 & & & 0 & 0 & 0 & 0 & 12 \\
\hline & Prp5 & 113 & gi|544217005 & & & 0 & 8 & 12 & 28 & 66 \\
\hline
\end{tabular}


TABLE 3. Continued

\begin{tabular}{|c|c|c|c|c|c|c|c|c|c|c|}
\hline \multirow[b]{2}{*}{ Particle or step } & \multirow[b]{2}{*}{ Protein } & \multirow{2}{*}{$\begin{array}{l}\mathrm{MW} \\
(\mathrm{kDa})\end{array}$} & \multirow{2}{*}{$\begin{array}{c}\text { Accession } \\
\text { number }\end{array}$} & \multicolumn{2}{|c|}{ colP } & \multicolumn{5}{|c|}{ 2'O-methyl pull-down } \\
\hline & & & & $\lg G$ & LSm & Control & U6 & U4 & U5 & U2 \\
\hline \multirow[t]{2}{*}{ U2 related } & Prp43 & 83 & gi|544213652 & & & 0 & 0 & 4 & 3 & 3 \\
\hline & Mud2 & 143 & gi|544217774 & & & 0 & 10 & 5 & 40 & 21 \\
\hline Complex A & Sub2 & 51 & gi|544210372 & 5 & 12 & & & & & \\
\hline \multirow[t]{3}{*}{ NTC } & Cef1 & 47 & gi|544216515 & & & 10 & 14 & 14 & 15 & 39 \\
\hline & Prp46 & 46 & gi|544216817 & & & 0 & 8 & 8 & 8 & 22 \\
\hline & Bud31 & 27 & gi|544210870 & & & 0 & 0 & 0 & 4 & 0 \\
\hline Complex B & Prp38 & 21 & gi|544212271 & & & 0 & 7 & 6 & 3 & 0 \\
\hline \multirow[t]{2}{*}{ Complex Bact } & Yju2 & 25 & gi|544214477 & & & 2 & 2 & 3 & 3 & 25 \\
\hline & Prp2 & 77 & gi|544210522 & & & 0 & 0 & 0 & 11 & 0 \\
\hline Second step & Prp22 & 140 & gi|544210916 & & & 0 & 8 & 3 & 4 & 19 \\
\hline \multirow[t]{3}{*}{ EJC } & THOC2 & 186 & gi|544210920 & 0 & 4 & 43 & 106 & 109 & 160 & 100 \\
\hline & Fal1 & 47 & gi|544212622 & & & 0 & 3 & 0 & 0 & 0 \\
\hline & Yra1 & 30 & gi|544211387 & 4 & 8 & & & & & \\
\hline SR & RSp31 & 34 & gi|544214602 & 5 & 6 & 25 & 16 & 27 & 49 & 69 \\
\hline \multirow[t]{6}{*}{ Misc. } & Pab1 & 104 & gi|544212541 & 10 & 30 & 14 & 76 & 101 & 49 & 98 \\
\hline & Quaking & 68 & gi|544209332 & 0 & 2 & 11 & 15 & 67 & 9 & 37 \\
\hline & Rpg1 & 143 & gi|544211285 & & & 8 & 15 & 19 & 13 & 19 \\
\hline & Mtr4 & 119 & gi|544209328 & 0 & 4 & 49 & 56 & 115 & 82 & 85 \\
\hline & Tub2 & 52 & gi|544214469 & 0 & 5 & & & & & \\
\hline & RPSA & 32 & gi|544218493 & & & 0 & 11 & 8 & 10 & 6 \\
\hline \multirow{7}{*}{$\begin{array}{l}\text { mRNA } \\
\text { degradation }\end{array}$} & Pat1 & 76 & gi|544209591 & 0 & 113 & 18 & 138 & 75 & 86 & 85 \\
\hline & Dhh1 & 52 & gi|544213271 & & & 0 & 7 & 7 & 9 & 2 \\
\hline & Dcp1 & 46 & gi|544213684 & 0 & $2^{\mathrm{a}}$ & & & & & \\
\hline & Dcp2 & 42 & gi|544212453 & & & 0 & 3 & 2 & 0 & 2 \\
\hline & Edc4 & 100 & gi|544210815 & 4 & 18 & 16 & 50 & 57 & 35 & 50 \\
\hline & Scd6 & 60 & gi|544218435 & 0 & 9 & 281 & 649 & 515 & 624 & 494 \\
\hline & Xrn1 & 168 & gi|544217023 & 3 & 23 & 409 & 1612 & 505 & 1617 & 798 \\
\hline
\end{tabular}

Blank cells indicate no peptides above threshold in any experiment; colored cells are at least twofold more enriched than the control; boxed cells are at least twofold more enriched than in other $2^{\prime} \mathrm{O}$-methyl experiments.

${ }^{\mathrm{a} O n l y}$ in one colP. 
TABLE 4. BLAST search results for previously unidentified splicing proteins

\begin{tabular}{|c|c|c|c|c|c|c|}
\hline $\mathrm{Cm}$ ID of mass spec protein & Protein query (species) & $\mathrm{Cm}$ hit rank & E-value & Reciprocal hit & RBH E-value & Identity \\
\hline \multirow[t]{5}{*}{ CMR356C } & Prp4 (Sc) & 24 & $8 \times 10^{-7}$ & 1.Prp4 & $9 \times 10^{-7}$ & $27 \%$ \\
\hline & $\operatorname{Prp}(\mathrm{Sp})$ & 24 & $6 \times 10^{-8}$ & 1.Prp4 & $5 \times 10^{-8}$ & $27 \%$ \\
\hline & PRP4 (Hs) & 24 & $7 \times 10^{-7}$ & 1.PRP4 & $3 \times 10^{-5}$ & $21 \%$ \\
\hline & U4-U6 60K (Dm) & 25 & $4 \times 10^{-8}$ & 1.U4-U6 60K & $2 \times 10^{-7}$ & $24 \%$ \\
\hline & Prp4 (Gs) & 26 & $4 \times 10^{-7}$ & 1.Prp4 & $2 \times 10^{-7}$ & $26 \%$ \\
\hline \multirow[t]{9}{*}{ CMS485C } & \multirow[t]{2}{*}{$\operatorname{Prp} 31$ (Sc) } & \multirow[t]{2}{*}{3} & \multirow[t]{2}{*}{$3 \times 10^{-4}$} & 1.Nop58 & $3 \times 10^{-6}$ & \multirow{3}{*}{$23 \%$} \\
\hline & & & & 2.Prp31 & $7 \times 10^{-6}$ & \\
\hline & \multirow[t]{2}{*}{ Prp31 (Sp) } & \multirow[t]{2}{*}{3} & \multirow[t]{2}{*}{$3 \times 10^{-3}$} & 1.Nop56 & $8 \times 10^{-8}$ & \\
\hline & & & & 3.Prp31 & $2 \times 10^{-3}$ & $36 \%$ \\
\hline & PRP31 (Hs) & 3 & $1 \times 10^{-6}$ & 1.PRP31 & $2 \times 10^{-5}$ & $27 \%$ \\
\hline & \multirow[t]{2}{*}{ Prp31 (Dm) } & \multirow[t]{2}{*}{3} & \multirow[t]{2}{*}{$9 \times 10^{-5}$} & 1.Nop56 & $2 \times 10^{-7}$ & \\
\hline & & & & 4.Prp31 & $3 \times 10^{-5}$ & $27 \%$ \\
\hline & $\operatorname{Prp} 31(\mathrm{Cr})$ & 3 & $6 \times 10^{-10}$ & 1.Prp31 & $1 \times 10^{-8}$ & $25 \%$ \\
\hline & Prp31 (Gs) & 3 & $4 \times 10^{-8}$ & 1.Prp31 & $1 \times 10^{-8}$ & $24 \%$ \\
\hline \multirow[t]{10}{*}{ CME166C } & \multirow[t]{2}{*}{ Prp2 (Sc) } & \multirow[t]{2}{*}{3} & \multirow[t]{2}{*}{$3 \times 10^{-90}$} & 1.Prp43 & $5 \times 10^{-123}$ & \\
\hline & & & & 5.Prp2 & $3 \times 10^{-99}$ & $33 \%$ \\
\hline & \multirow[t]{2}{*}{ Cdc28 (Sp) } & \multirow[t]{2}{*}{3} & \multirow{2}{*}{$5 \times 10^{-95}$} & 1.Prh1 & $1 \times 10^{-133}$ & \\
\hline & & & & 5.Prp2 & $3 \times 10^{-104}$ & $34 \%$ \\
\hline & \multirow[t]{2}{*}{ DHX16 (Hs) } & \multirow[t]{2}{*}{3} & \multirow[t]{2}{*}{$2 \times 10^{-102}$} & 1.DHX8 & $6 \times 10^{-127}$ & \\
\hline & & & & 25.DHX16 & $5 \times 10^{-112}$ & $36 \%$ \\
\hline & \multirow[t]{2}{*}{ lethal(2)37Cb (Dm) } & \multirow{2}{*}{3} & \multirow{2}{*}{$2 \times 10^{-103}$} & 1.Prp22 & $9 \times 10^{-126}$ & \\
\hline & & & & 4.lethal $(2) 37 \mathrm{Cb}$ & $7 \times 10^{-111}$ & $35 \%$ \\
\hline & \multirow[t]{2}{*}{ ESP3 (At) } & \multirow[t]{2}{*}{3} & \multirow[t]{2}{*}{$2 \times 10^{-111}$} & 1.PRP22 & $6 \times 10^{-121}$ & \\
\hline & & & & 5.ESP3 & $2 \times 10^{-118}$ & $35 \%$ \\
\hline
\end{tabular}

The rank and identity of the reciprocal hit is noted. $\mathrm{RBH}$ E-values are reported for the top hit as well as for the predicted protein when it is not the top hit.

Sc, Saccharomyces cerevisiae; Sp, Schizosaccharomyces pombe; Hs, Homo sapiens; Dm, Drosophila melanogaster; Gs, Galdieria sulphuraria; Cr, Chlamydomonas reinhardtii; At, Arabidopsis thaliana.

downs with oligos directed against U4, U5, and U2 snRNAs. Northern analysis again confirmed successful purification of the targeted snRNAs relative to controls (Fig. 6, lanes 4,6,10), with little copurification except for U6 in the U4 pull-down. Mass spectrometric results showed strong enrichment for the expected snRNP-specific proteins, although the Sm proteins were more highly enriched in the U2 pull-down than in any of the others, perhaps due to the higher efficiency snRNA isolation (Table 3). Unexpectedly, we detected substantial enrichment of NTC proteins, particularly with U2, as well as $\mathrm{B}$ complex and $\mathrm{B}^{\text {act }}$ complex proteins, and several other miscellaneous splicing proteins. We also observed enrichment of several U2 proteins in the U4, U5, and U6 snRNA pulldowns, despite low levels of U2 snRNA detected on the Northern. Consistent with the existence of a U4/U6.U5 trisnRNP, U5 proteins copurify with the U4 and U6 snRNAs, but their presence in the U2 pull-down was unexpected. One of the copurified proteins was clearly a DEAH-box helicase, which BLAST searches suggested might be Prp2 (Table 4), although it does not have the $\mathrm{N}$-terminal extension canonically associated with Prp2 (Supplemental Fig. S6; King and Beggs 1990). Notably, mRNA degradation proteins copurified at similar levels with all of the snRNAs, raising the intriguing possibility of a spliceosome-associated RNA degradation complex.
The existence of just one CmLSm complex, along with the unexpected association of Pat 1 mRNA degradation proteins with the splicing machinery, suggested that $C$. merolae may not harbor a cytoplasmic fraction of the Pat 1 complex. In order to determine its cellular localization, we used anti-LSm antiserum to perform indirect immunofluorescence microscopy on C. merolae cells (Fig. 7). The chloroplast of C. merolae cells is autofluorescent over a broad range of wavelengths, and is therefore visible in the FITC (green) and TXRED (red) channels (Fig. 7A). We could readily detect the nucleus and chloroplast from DAPI staining in cells with no antiserum treatment (Fig. 7B), and we detected no green autofluorescence signal outside of the chloroplast when the outline of the DAPI signal was superimposed on the FITC (green) image (Fig. 7C,D arrow). As a further test, we digitally subtracted the DAPI (blue) image from the FITC (green) image, which again showed that there is no green signal outside of the chloroplast (Fig. 7E). In contrast, we easily detected a green signal outside the chloroplast in cells stained with anti-LSm antiserum (Fig. 7F). This demonstrated that the antibodies specifically recognized an antigen in C. merolae cells and were readily visible above the background autofluorescence.

To determine whether the CmLSm proteins are exclusively nuclear, we compared the FITC (green) signal to the DAPI (blue), as shown in two representative cells (Fig. 7G-N). In 
TABLE 5. BLAST search results for mRNA degradation proteins

\begin{tabular}{|c|c|c|c|c|c|}
\hline Protein & Organism & Top hit in C. merolae strain 10D & $\mathrm{Cm}$ ID & E-value & Identity \\
\hline \multicolumn{6}{|l|}{ Pat1 } \\
\hline PAT1 & $\mathrm{Hs}$ & ATP-binding cassette sub-family $\mathrm{C}$ & CMD133C & 1 & $29 \%$ \\
\hline Pat1 & Sc & Transcription factor APF1 & CMM052C & $1 \times 10^{-1}$ & $24 \%$ \\
\hline Pat1 & Sp & Probable serine-rich pumilio family RNA-binding domain protein & CMR037C & $1 \times 10^{-2}$ & $23 \%$ \\
\hline PAT1 & At & Hypothetical protein & CMB102C & $1 \times 10^{-1}$ & $24 \%$ \\
\hline Patr-1 & $\mathrm{Dm}$ & Probable sodium/hydrogen antiporter & CMS154C & 3 & $25 \%$ \\
\hline \multicolumn{6}{|l|}{ Dhh1 } \\
\hline DDX6 & $\mathrm{Hs}$ & RNA helicase & CML140C & 0 & $67 \%$ \\
\hline Dhh1 & Sc & RNA helicase & CML140C & 0 & $67 \%$ \\
\hline Ste13 & Sp & RNA helicase & CML140C & 0 & $71 \%$ \\
\hline RH8 & At & RNA helicase & CML140C & 0 & $70 \%$ \\
\hline Me31B & $\mathrm{Dm}$ & RNA helicase & CML140C & 0 & $65 \%$ \\
\hline \multicolumn{6}{|l|}{ Dcp1 } \\
\hline DCP1 & $\mathrm{Hs}$ & Probable mRNA-decapping enzyme complex component DCP1 & CMM070C & $4 \times 10^{-11}$ & $30 \%$ \\
\hline Dcp1 & Sc & Probable mRNA-decapping enzyme complex component DCP1 & CMM070C & 4 & $29 \%$ \\
\hline Dcp1 & Sp & Probable mRNA-decapping enzyme complex component DCP1 & CMM070C & $5 \times 10^{-11}$ & $35 \%$ \\
\hline DCP1 & At & Probable mRNA-decapping enzyme complex component DCP1 & CMM070C & $4 \times 10^{-18}$ & $33 \%$ \\
\hline Dcp1 & Gs & Probable mRNA-decapping enzyme complex component DCP1 & CMM070C & $4 \times 10^{-4}$ & $31 \%$ \\
\hline \multicolumn{6}{|c|}{ 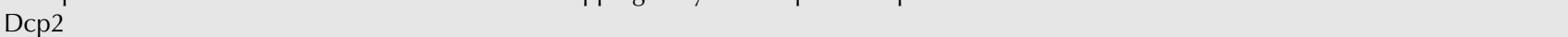 } \\
\hline DCP2 & $\mathrm{Hs}$ & mRNA-decapping enzyme complex component DCP2 & CMJ226C & $9 \times 10^{-50}$ & $38 \%$ \\
\hline Dср2 & Sc & mRNA-decapping enzyme complex component DCP2 & CMJ226C & $1 \times 10^{-42}$ & $31 \%$ \\
\hline Dcp2 & Sp & mRNA-decapping enzyme complex component DCP2 & CMJ226C & $5 \times 10^{-52}$ & $37 \%$ \\
\hline DCP2 & At & mRNA-decapping enzyme complex component DCP2 & CMJ226C & $3 \times 10^{-53}$ & $37 \%$ \\
\hline Dcp2 & Gs & mRNA-decapping enzyme complex component DCP2 & CMJ226C & $1 \times 10^{-65}$ & $42 \%$ \\
\hline \multicolumn{6}{|l|}{ Edc4 } \\
\hline EDC4 & $\mathrm{Hs}$ & Similar to autoantigen & CMF168C & $5 \times 10^{-14}$ & $31 \%$ \\
\hline VCS & At & Similar to autoantigen & CMF168C & $2 \times 10^{-10}$ & $34 \%$ \\
\hline Edc4 & Gs & Similar to autoantigen & CMF168C & $3 \times 10^{-14}$ & $29 \%$ \\
\hline Ge-1 & $\mathrm{Dm}$ & Similar to autoantigen & CMF168C & $3 \times 10^{-7}$ & $34 \%$ \\
\hline Edc4 & $\mathrm{Dr}$ & Similar to autoantigen & CMF168C & $3 \times 10^{-12}$ & $26 \%$ \\
\hline \multicolumn{6}{|l|}{ Xrn1 } \\
\hline XRN1 & Hs & Exonuclease & CMQ316C & $4 \times 10^{-152}$ & $40 \%$ \\
\hline Xrn1 & Sc & Deoxyribonuclease & CMR447C & $3 \times 10^{-134}$ & $35 \%$ \\
\hline Exo2 & Sp & Deoxyribonuclease & CMR447C & $1 \times 10^{-157}$ & $30 \%$ \\
\hline XRN1 & At & Deoxyribonuclease & CMR447C & $2 \times 10^{-137}$ & $39 \%$ \\
\hline Xrn1 & Gs & Deoxyribonuclease & CMR447C & 0 & $34 \%$ \\
\hline \multicolumn{6}{|l|}{ Edc3 } \\
\hline EDC3 & $\mathrm{Hs}$ & Tryptophan synthase $\alpha$ chain & CymeСp007 & 2 & $32 \%$ \\
\hline Edc3 & Sc & Hypothetical protein, conserved & CMM009C & $7 \times 10^{-3}$ & $20 \%$ \\
\hline Edc3 & Sp & Hypothetical protein, conserved & CMM009C & $5 \times 10^{-1}$ & $24 \%$ \\
\hline Edc3 & $\mathrm{Dm}$ & Arogenate/prephenate dehydrogenase & CMS326C & $8 \times 10^{-1}$ & $26 \%$ \\
\hline Edc3 & $\mathrm{Dr}$ & Similar to GATA transcription factor areB $\gamma$ & CMB029C & 2 & $38 \%$ \\
\hline \multicolumn{6}{|c|}{ 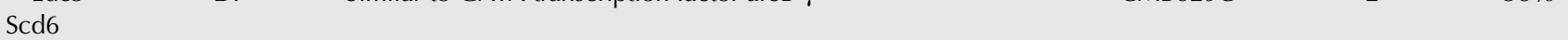 } \\
\hline LSm14B & $\mathrm{Hs}$ & Hypothetical protein, conserved & СMT375C & $1 \times 10^{-18}$ & $51 \%$ \\
\hline Scd6 & Sc & Hypothetical protein, conserved & СMT375C & $2 \times 10^{-11}$ & $41 \%$ \\
\hline Sum2 & Sp & Hypothetical protein, conserved & СMT375C & $7 \times 10^{-20}$ & $53 \%$ \\
\hline DCP5 & At & Hypothetical protein, conserved & CMT375C & $1 \times 10^{-19}$ & $55 \%$ \\
\hline Tral & $\mathrm{Dm}$ & Hypothetical protein, conserved & СMT375C & $2 \times 10^{-16}$ & $47 \%$ \\
\hline
\end{tabular}

Hs, Homo sapiens; Sc, Saccharomyces cerevisiae; Sp, Schizosaccharomyces pombe; At, Arabidopsis thaliana; Gs, Galdiaria sulphuraria; Dm, Drosophila melanogaster; Dr, Danio rerio.

merged images, the antiserum staining appears to have a diffuse, nuclear portion, as well as a stronger, punctate pattern outside the nucleus (Fig. 7G,K). To test this, we made outlines of the merged chloroplast autofluorescence and DAPI signals (Fig. 7J,N) and superimposed them on the antiLSm FITC (green) images (Fig. 7I,M). The arrows indicate punctae distributed at least partially outside the nuclear and chloroplast boundaries. As a further test, we digitally subtracted the DAPI (blue) signal from the anti-LSm (green) signal, again demonstrating substantial LSm staining outside the nuclear boundary (Fig. 7O). Taken together, these data support the presence of LSm proteins in the cytoplasm.

To investigate the localization of $\mathrm{CmLSm}$ proteins in more detail, we used immunoelectron microscopy (IEM) with gold-labeled antibodies to assess the distribution of CmLSm proteins in C. merolae cells. In transverse sections 
TABLE 6. LOMETS results for homology models of CMB102C

\begin{tabular}{|c|c|c|c|c|c|c|c|c|}
\hline Rank & Template & Protein (species) & Alignment length & Coverage & Z-score & Identity & Confidence score & Program \\
\hline 1 & 4nOa_H & Pat1 (Sc) & 257 & 0.366 & 79.353 & 0.15 & High & HHSEARCH2 \\
\hline 2 & 4ogp_A & Pat1 (Sc) & 249 & 0.355 & 80.002 & 0.14 & High & HHSEARCH2 \\
\hline 3 & 2 xesA0 & Pat1 (Hs) & 229 & 0.326 & 9.721 & 0.18 & Medium & pGenTHREADER \\
\hline 4 & 4ui9O & APC5 $(\mathrm{Hs})$ & 654 & 0.932 & 15.113 & 0.09 & Medium & Neff-PPAS \\
\hline 5 & $1 \mathrm{vw} 1 \mathrm{~A}$ & TcdA1 (PI) & 678 & 0.967 & 4.544 & 0.14 & Medium & PROSPECT2 \\
\hline 6 & 4ogp_A & Pat1 (Sc) & 248 & 0.353 & 13.539 & 0.15 & Medium & HHSEARCH \\
\hline 7 & 4 fyqa & Aminopeptidase $\mathrm{N}(\mathrm{Hs})$ & 650 & 0.927 & 9.032 & 0.15 & Medium & SP3 \\
\hline 8 & 3jav_A & IP3R1 channel $(\mathrm{Rn})$ & 640 & 0.912 & 36.400 & 0.12 & Low & FFAS-3D \\
\hline 9 & 4ogp_A & Pat1 (Sc) & 249 & 0.355 & 16.386 & 0.15 & Low & HHSEARCH I \\
\hline 10 & $5 a 9 q^{1}$ & NUP160 (Hs) & 654 & 0.932 & 7.440 & 0.09 & Low & SPARKS-X \\
\hline
\end{tabular}

through the nucleus and surrounding cytoplasm (Fig. 8, left panel) and in longitudinal sections through the nucleus, mitochondrion, and chloroplast (Fig. 8, right panel) gold particles were observed in the nucleus (tailed arrows) and cytoplasm (solid arrows), but not in other organelles or cellular compartments. This clearly demonstrates that a substantial proportion of CmLSm proteins are indeed cytoplasmic. Our results support a nuclear function for the CmLSm complex in splicing, while the cytoplasmic fraction is consistent with an LSm-associated mRNA degradation complex.

\section{DISCUSSION}

Bioinformatic searches identified seven distinct LSm proteins in C. merolae (Stark et al. 2015). LSm4 is encoded by paralogous genes (CMG061c and CMT545c) that differ at only three positions but produce identical proteins. Since most organisms in which LSm proteins have been studied have at least eight LSm proteins belonging to two complexes, we sought to determine whether the CmLSm proteins have a splicing function in the nucleus or an mRNA degradation function in the cytoplasm. Our IP-MS and $2^{\prime} \mathrm{OMe}-\mathrm{MS}$ data, in vitro binding measurements, and microscopy are consistent with the CmLSm complex playing a role in both processes. In addition, the data raise the possibility of a spliceosome-associated RNA degradation complex in C. merolae.

Previous work has characterized LSm complexes in other organisms with reduced spliceosomes. In Leishmania tarentolae, proteomic analysis in the absence of a sequenced genome revealed the presence of LSm2, LSm3, LSm4, LSm5, and LSm8 (Tkacz et al. 2010). This complex was associated with other splicing components, but not with mRNA degradation factors. Earlier work in Trypanosoma brucei found a single complex, lacking LSm1, that associated with U6, but was not detectable in cytoplasmic P-bodies or stress granules, again arguing against a role in mRNA degradation (Tkacz et al. 2008). In contrast, however, depletion of T. brucei LSm8 resulted in increased mRNA stability (Liu et al. 2004), raising the possibility that the single $T$. brucei LSm complex may function in both splicing and mRNA decay. Our microscopic evidence demonstrates the presence of CmLSm proteins in the cytoplasm that could be involved in mRNA degradation. Consistent with this, we found a possible C. merolae Pat 1 homolog as well as the other known Pat1-associated mRNA degradation proteins (except Edc3) that copurified with the CmLSm complex, and, unexpectedly, with all four snRNAs. Further work will be required to confirm the function of the Patl complex in mRNA degradation, as well as to test the possibility of a spliceosome-associated RNA

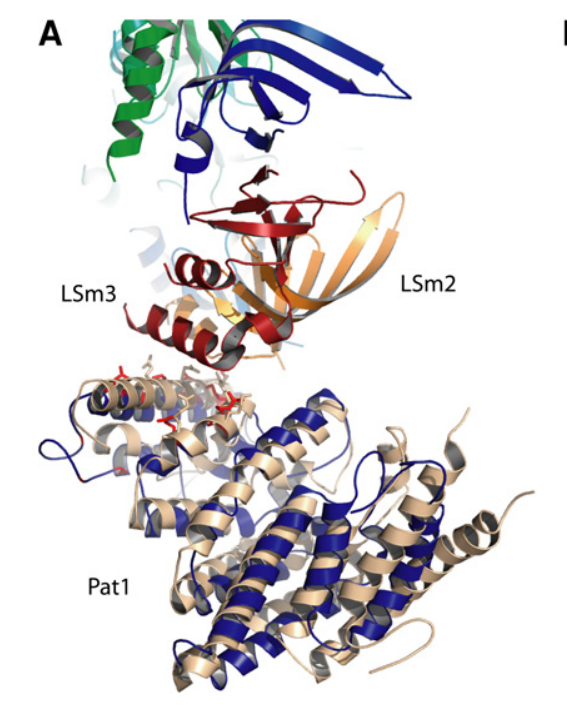

B

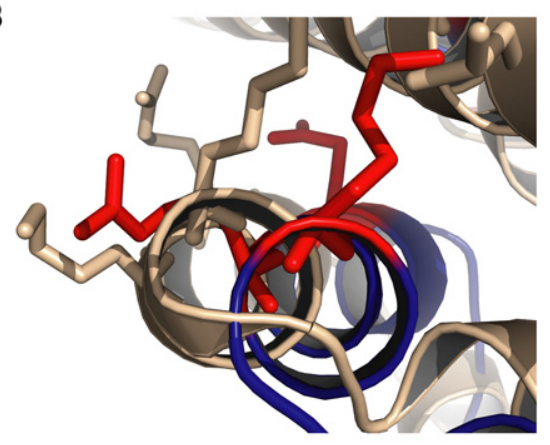

FIGURE 5. Homology modeling of C. merolae Pat1 candidate on LSm/Pat1 structure 4N0A. (A) Overlap of CmPat1 model (blue) with Pat1 (wheat) from S. cerevisiae (Wu et al. 2014) showing interactions with LSm 2 and LSm3. CmPat1 side chains predicted to contact the LSm proteins are highlighted in red. $(B)$ Close-up of Pat1 helix 2a, showing similar position and orientation of CmPatl (red) and ScPatl (wheat) side chains that contact the LSm proteins. 


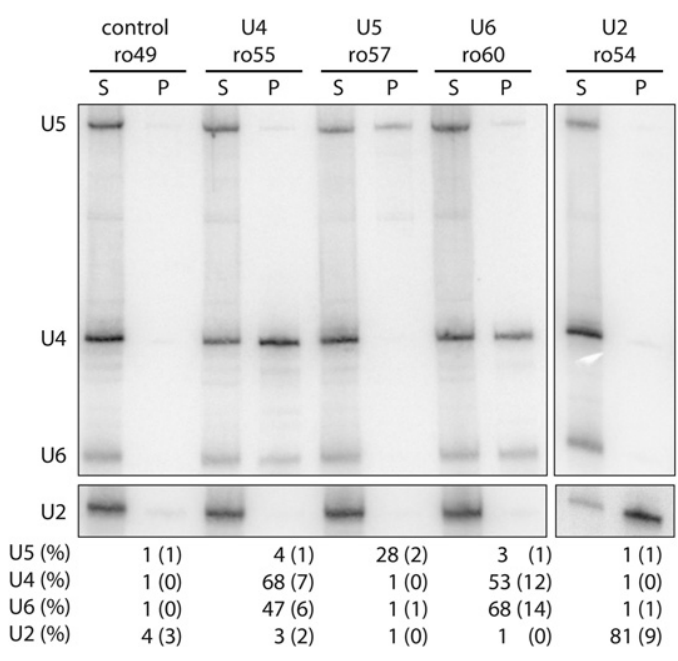

FIGURE 6. 2'O-methyl antisense oligonucleotide pull-downs of $C$. merolae snRNAs. Northern analysis of snRNAs in pull-down supernatants $(\mathrm{S})$ and pellets $(\mathrm{P})$. The identity of snRNAs on the blot is indicated at left, while the oligo used in the pull-down, and its target snRNA, is indicated above each lane. The average fraction of each snRNA isolated in each experiment is given below $(n \geq 3)$ with standard deviations in parentheses.

degradation particle. A splicing-associated degradosome would be consistent with evidence for a spliceosomal discard pathway that rejects aberrant pre-mRNA transcripts for degradation (Burgess and Guthrie 1993; Koodathingal et al. 2010; Mayas et al. 2010; Koodathingal and Staley 2013). It would also be consistent with recent evidence for a nuclear Pat1 fraction (Marnef et al. 2012), although experiments in S. cerevisiae suggest that nuclear Pat1 is not involved in premRNA degradation (Muppavarapu et al. 2016).

These observations raise the question of how one LSm complex would be targeted to two cellular compartments. In $S$. cerevisiae, no single LSm is sufficient for nuclear exclusion or accumulation, although the $\mathrm{N}$ termini of LSm1 and LSm8 play a role in targeting (Reijns et al. 2009). One possibility in C. merolae is that cytoplasmic localization of the LSm/Patl complex is the default, while targeting to the nucleus occurs via Pat1-snRNP interactions. Interestingly, it has been shown in trypanosomes that Sm proteins can functionally substitute for LSm proteins (Palfi et al. 2000), so it is conceivable that the nuclear CmLSm complex contains an Sm protein responsible for nuclear localization in place of LSm8. Our in vitro data, however, make it clear that the CmLSm complex is competent to bind U6 snRNA without the participation of Sm proteins.

The protein identifications presented here empirically substantiate our bioinformatic predictions of splicing proteins in C. merolae (Stark et al. 2015). Of the 42 predicted proteins, we found all but Dib1, Msl5/BBP, Prp16, and the cap binding complex proteins Sto1 and $\mathrm{Cbc} 2$ enriched at least twofold above background in our copurification experiments. We also observed peripheral, putative splicing proteins, specifically Fal1, Rsp31, Rpg1, Mtr4, and RPSA. In addition, we found candidates for Prp4 and Prp31 that are clearly enriched in U4 and U6 snRNA pull-downs, although their homology with known proteins is tenuous. We observed a protein with some similarity to Prp2 in association with the U5 snRNA, bringing the count of core splicing proteins in C. merolae to 45 . Notably, despite copurifying the mRNA degradation machinery and several previously unidentified splicing proteins, we failed to observe any U1-associated proteins, supporting our previous conclusion that the U1 snRNP is absent in this organism.

The $K_{d}$ value of $120 \pm 15 \mathrm{nM}$ that we observed for the interaction between full-length U6 and the CmLSm complex is similar to the reported $K_{d}$ of $52 \pm 7 \mathrm{nM}$ for the interaction between yeast U6 and LSm2-8 (Zhou et al. 2014). This suggests that the CmLSm complex might interact with U6 in a similar
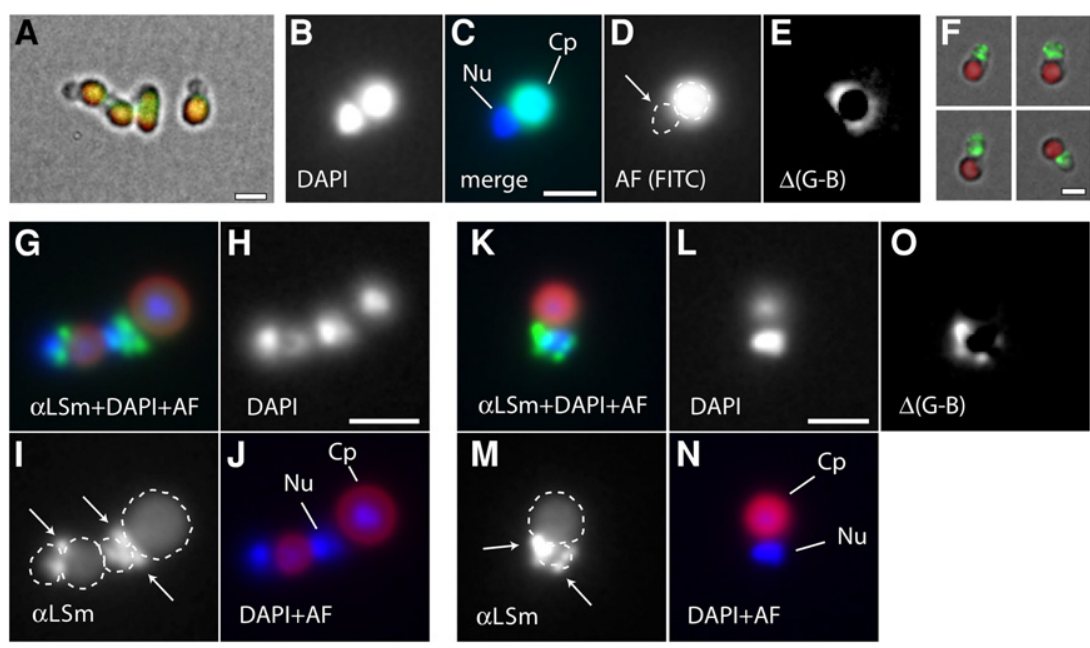

FIGURE 7. CmLSm proteins localize in the nucleus and in bright, cytoplasmic foci. (A) Merged bright field and autofluorescence (green, red) images of control $C$. merolae cells (no primary antiserum). (B) DAPI signal from control cells. $(C)$ Merged DAPI and autofluorescence (FITC) images. Nucleus $(\mathrm{Nu})$ and chloroplast $(\mathrm{Cp})$ are indicated. $(D)$ Green autofluorescence with dashed outline of the DAPI signal superimposed. Arrow indicates the absence of signal in the nuclear region. (E) Digitally subtracted image (green-blue) of the same cell as in $B-D$. (F) Merged bright field, autofluorescent (red), and anti-LSm (green) images from anti-LSm-probed cells. $(G)$ Merged DAPI (blue), autofluorescent (red), and anti-LSm (green) images of two cells. $(H)$ DAPI, $(I)$ anti-LSm, and $(J)$ merge of DAPI plus autofluorescence with organelles indicated as in $C$. The outline of the signal from the latter image (dashed lines) was superimposed on the anti-LSm image $(I)$, and arrows indicate green (LSm) signal extending beyond the borders of the nucleus and chloroplast. $(K-N)$ As in $(G-J)$. $(O)$ Digital subtraction of the DAPI signal $(L)$ from the anti-LSm signal $(M)$ demonstrating LSm signal outside of the nucleus. Scale bars, $2 \mu \mathrm{m}$. 

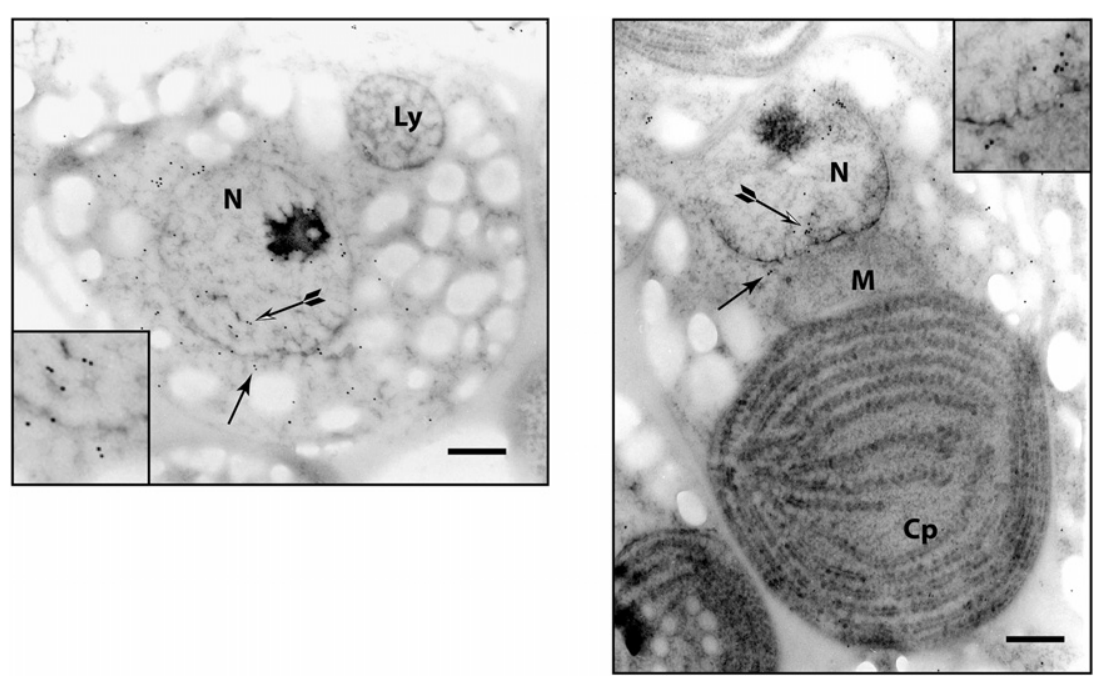

FIGURE 8. Immunoelectron microscopy confirms cytoplasmic fraction of CmLSm proteins. Transverse (left) and longitudinal (right) sections of C. merolae cells showing nuclear (N), lysosomal (Ly), mitochondrial (M), and chloroplast (Cp) compartments. Gold particles coupled to anti-CmLSm antibodies demonstrate nuclear (tailed arrows) and cytoplasmic (solid arrows) localization. Insets show particles on either side of the nuclear membrane in regions highlighted by arrows. Scale bar, $200 \mathrm{~nm}$.

\section{Cyanidioschyzon merolae bioinformatic analysis}

We obtained protein sequences for the LSm, Prp4, Prp31, Prp2, and mRNA degradation pathway genes from the NCBI Homologene database and analyzed these sequences using NCBI Protein BLAST to find homologs in C. merolae using reciprocal best hit methodology (Ward and Moreno-Hagelsieb 2014; Stark et al. 2015). Protein sequences were aligned using MUSCLE (Edgar 2004) and formatted with MView (Brown et al. 1998). For the phylogenetic tree, sequences were aligned with Clustal Omega ( $\mathrm{Li}$ et al. 2015), and trees were calculated with PhyML (Guindon et al. 2010), and visualized and edited with FigTree. We used PSI-BLAST (Altschul et al. 1997) to identify homologs of the uncharacterized proteins from C. merolae that were enriched in the IP-MS and/or 2'OMe-MS experiments. Additionally, to confirm the identity of the proposed CmPat 1 homo$\log$ we used the structure modeling (threading) program, LOMETS (Wu and Zhang 2007), visualized with PyMol (Schrödinger). manner to how it does in yeast. Additionally, our CmLSm complex looks comparable to the yeast LSm complex at the level of electron microscopy on negatively stained samples (see Fig. 2 of Achsel et al. 1999). The toroidal appearance of the complex, its purification by a single tag on LSm6, and the Hill coefficient for binding of approximately one all argue for a preformed complex that binds RNA in a single step. Although a putative cross-link between the yeast LSm complex and the U6 stem was found (Karaduman et al. 2006), an oligo containing only the CmLSm binding site bound comparably to an oligo with the adjacent stem $\left(K_{d}\right.$ $=150 \mathrm{nM}$ versus $180 \mathrm{nM}$, respectively), as well as to the complete snRNA $\left(K_{d}=120 \mathrm{nM}\right)$. These results suggest that the CmLSm complex only binds the extreme $3^{\prime}$ end of U6, but further work will be required to fully characterize the CmLSm binding determinants.

Our results suggest that the only proteins associated with the U6 snRNP are the LSm proteins. Since C. merolae is missing Prp24, which usually associates with the U6 snRNP and promotes U4/U6 di-snRNP formation, this could indicate that the LSm proteins carry out this function. LSm proteins have previously been shown to promote U4/U6 base-pairing in vitro (Achsel et al. 1999). We have shown that U4 and U6 snRNAs are indeed capable of base-pairing in C. merolae (Stark et al. 2015), but have yet to investigate whether the presence of LSm proteins enhances this interaction.

\section{MATERIALS AND METHODS}

See Supplemental Material for more details.

\section{LSm cloning, protein preparation, and verification by mass spectrometry}

We amplified all seven LSm genes from C. merolae genomic DNA by PCR, and combined these genes sequentially into a single coexpression plasmid, pQLink, using ligation-independent cloning (Scheich et al. 2007; Dunn 2014). We expressed the resulting plasmid, with His-tagged LSm6, in Rosetta(DE3)pLysS cells using auto-inducing media ZYM-5052 (Studier 2005), then lysed the cells and purified the protein complex in two steps using nickel affinity chromatography, followed by gel filtration. To confirm by mass spectrometry that all seven LSm subunits were present in the final concentrated sample, the sample was denatured and digested with trypsin. Reactions were quenched with formic acid and loaded directly onto a C18 reverse-phase column for LC-MS/MS.

\section{Production of $\mathrm{CmLSm}$ antibodies and affinity purification}

We injected a rabbit with purified CmLSm protein complex in order to generate polyclonal antibodies against the LSm proteins. We affinity purified the anti-LSm antibodies from the crude serum using cross-linked CmLSm complex coupled to sepharose, followed by acid elution (Harlow and Lane 1988).

\section{Electrophoretic mobility shift assays}

EMSA reactions contained ${ }^{32} \mathrm{P}$-labeled, in vitro transcribed (IVT) U6 snRNA at a final concentration of $10 \mathrm{nM}$, and LSm protein complex at the concentrations indicated in Figure 3. Following incubation for $15 \mathrm{~min}$ at room temperature, we electrophoresed samples on a native polyacrylamide gel at $4^{\circ} \mathrm{C}$ and imaged the gel on a phosphorimager screen. For U4 binding measurements, we followed the 
same procedure as above, except we used a fluorescein-labeled U4 oligo at a final concentration of $100 \mathrm{nM}$, and visualized the gel with a fluorescent scanner. We used Kaleidagraph (Synergy Software) to fit the data, measured in triplicate, to a modified Hill equation and generate $K_{d}$ values.

\section{Preparation of $C$. merolae whole-cell extract}

Extract from the 10D strain of C. merolae was prepared following the cryo-grinding method for yeast splicing extract using a mortar and pestle (Ansari and Schwer 1995; Dunn and Rader 2014), or using a planetary ball mill (Trahan et al. 2016), with some modifications. Briefly, we grew cells in MA2 media, harvested cells in log phase, and injected them into liquid nitrogen using a syringe. We ground the cells to a fine powder in the presence of liquid nitrogen so that the grindate remained frozen throughout. Grindate was thawed quickly by the addition of cold lysis buffer. The cell lysate was sonicated briefly and then centrifuged to remove starch and cellular debris. Extract was either used immediately, or glycerol was added to a final concentration of $10 \%$ and the extract was snap frozen in liquid nitrogen and stored at $-80^{\circ} \mathrm{C}$.

\section{LSm coimmunoprecipitation}

To immunoprecipitate the LSm complex from C. merolae extract, we cross-linked anti-LSm serum or non-immune serum to Protein A Sepharose using dimethylpimelimidate. For coimmunoprecipitation followed by mass spectrometry (IP-MS) we conjugated affinity purified anti-LSm antibodies or rabbit IgG to magnetic M270 Epoxy Dynabeads (Oeffinger et al. 2007). C. merolae extract was incubated with cross-linked beads followed by extensive washing to remove nonspecific proteins. Proteins were eluted with Laemmli buffer for analysis by Western blot, or proteins were removed by treatment with Proteinase K followed by phenol:chloroform extraction, and the RNA was EtOH-precipitated for analysis by Northern blot. For IP-MS, we performed on-bead trypsin digestion of the bound proteins with $750 \mathrm{ng}$ of trypsin in $50 \mu \mathrm{L}$ of $20 \mathrm{mM}$ Tris- $\mathrm{HCl} \mathrm{pH} 8.0$ at $37^{\circ} \mathrm{C}$ overnight in a thermomixer set at $900 \mathrm{RPM}$ (Gingras et al. 2007). These reactions were quenched with formic acid and then cleaned on a C18 ZipTip prior to loading onto a C18 reverse-phase column for LC-MS/MS analysis as previously described (Trahan et al. 2016).

\section{2'O-methyl oligo pull-downs}

To isolate the snRNAs and their associated proteins from C. merolae extract, we first incubated extract with a biotinylated RNA oligo complimentary to a short region of each snRNA, or a control oligo, and then added magnetic beads coated with Neutravidin. Beads were washed extensively and then the same procedures as in the LSm coimmunoprecipitation were followed for Northern blot analysis and mass spectrometry.

\section{Mass spectrometry}

For details on sample preparation, see Supplemental Methods. Raw files were first converted to mzML format using ProteoWizard (v3.0.9322) and the AB SCIEX MS Data Converter (v1.3 beta), and then searched using Mascot and Comet (v2014.02 rev. 2) search engines. The searches were performed against the RefSeq database release 57 including a decoy set. One missed cleavage was allowed in the search parameters for +2 to $4+$ precursor ions with a 10 ppm error tolerance, and a 0.6 Da error tolerance on fragmented ions. The output from each search engine were analyzed through the Trans-Proteomic Pipeline (Deutsch et al. 2010) (v4.7 POLAR VORTEX rev 1) by means of the iProphet pipeline using a $5 \%$ FDR (Shteynberg et al. 2011).

\section{Immunofluorescence microscopy}

We synchronized the division of $C$. merolae cells by subjecting them to a $12 \mathrm{~h}$ dark-12 h light cycle. We collected cells $10 \mathrm{~h}$ into the second light cycle to isolate cells in interphase (Suzuki et al. 1994). Cells were fixed in paraformaldehyde/methanol and permeabilized with Triton X-100. Cells were blocked with BSA and then incubated with anti-LSm serum, followed by a fluorescent secondary antibody. Control reactions were performed as above, with the exception of incubating in $1 \times$ PBS instead of anti-LSm antiserum. We visualized the cells with an Olympus BX61 fluorescence microscope.

\section{Electron microscopy}

We prepared negative stain specimens by adsorbing purified proteins to glow discharged carbon-coated copper grids and staining with uranyl formate. We took images of the specimens on a Tecnai Spirit transmission electron microscope (FEI) and interactively selected particles from the micrographs.

\section{Immunoelectron microscopy}

Immunoelectron microscopy was performed as described previously ((Yagisawa et al. 2007). Grid sections were incubated with affinity purified anti-LSm antibodies followed by goat antirabbit IgG conjugated with colloidal gold. Samples were stained with uranyl acetate and visualized with an electron microscope.

\section{SUPPLEMENTAL MATERIAL}

Supplemental material is available for this article.

\section{ACKNOWLEDGMENTS}

We thank Matt Halstead and Kelly Hrywkiw for initial work on recombinant LSm protein expression. Dr. Takayuki Fujiwara shared important tips for C. merolae microscopy. Naomi Fast and Andrew MacMillan provided helpful discussions on this project. Farid Jalali (Olympus) was instrumental in helping us optimize data collection on the fluorescence microscope. We thank the members of the Rader and Oeffinger laboratories for thoughtful discussion of this work. Denis Faubert and his team in the mass spec facility at IRCM provided invaluable assistance and advice. This work was supported by an undergraduate Research Project Award from the UNBC Office of Research (K.A.R.), the Natural Sciences and Engineering Research Council (NSERC) of Canada Discovery Grant 298521 to S.D.R., NSERC Discovery Grant RGPIN-201603737 to R.D.B., NSERC Discovery Grant RGPIN 418157-12 to 
C.K.Y., NSERC Discovery Grant 341453-12 to R.P.F., and NSERC Discovery Grant RGPIN-2015-06586 to M.O.

Received August 15, 2016; accepted March 15, 2017.

\section{REFERENCES}

Achsel T, Brahms H, Kastner B, Bachi A, Wilm M, Lührmann R. 1999. A doughnut-shaped heteromer of human Sm-like proteins binds to the $3^{\prime}$-end of U6 snRNA, thereby facilitating U4/U6 duplex formation in vitro. EMBO J 18: 5789-5802.

Altschul SF, Madden TL, Schäffer AA, Zhang J, Zhang Z, Miller W, Lipman DJ. 1997. Gapped BLAST and PSI-BLAST: a new generation of protein database search programs. Nucleic Acids Res 25: 3389-3402.

Ansari A, Schwer B. 1995. SLU7 and a novel activity, SSF1, act during the PRP16-dependent step of yeast pre-mRNA splicing. EMBO J 14: 4001-4009.

Beggs JD. 2005. Lsm proteins and RNA processing. Biochem Soc Trans 33: $433-438$.

Berget SM, Moore C, Sharp PA. 1977. Spliced segments at the $5^{\prime}$ terminus of adenovirus 2 late mRNA. Proc Natl Acad Sci 74: 3171-3175.

Bizarro J, Dodré M, Huttin A, Charpentier B, Schlotter F, Branlant C, Verheggen C, Massenet S, Bertrand E. 2015. NUFIP and the HSP90/R2TP chaperone bind the SMN complex and facilitate assembly of U4-specific proteins. Nucleic Acids Res 43: 8973-8989.

Black CS, Garside EL, MacMillan AM, Rader SD. 2016. Conserved structure of Snu13 from the highly reduced spliceosome of Cyanidioschyzon merolae. Protein Sci 25: 911-916.

Bouveret E, Rigaut G, Shevchenko A, Wilm M, Séraphin B. 2000. An Sm-like protein complex that participates in mRNA degradation. EMBO J 19: 1661-1671.

Brown NP, Leroy C, Sander C. 1998. MView: a web-compatible database search or multiple alignment viewer. Bioinformatics 14: 380-381.

Burgess SM, Guthrie C. 1993. A mechanism to enhance mRNA splicing fidelity: the RNA-dependent ATPase Prp16 governs usage of a discard pathway for aberrant lariat intermediates. Cell 73: 1377-1391.

Cary GA, Vinh DBN, May P, Kuestner R, Dudley AM. 2015. Proteomic analysis of Dhh1 complexes reveals a role for Hsp40 chaperone Ydj1 in yeast P-body assembly. G3 (Bethesda) 5: 2497-2511.

Chow LT, Gelinas RE, Broker TR, Roberts RJ. 1977. An amazing sequence arrangement at the $5^{\prime}$ ends of adenovirus 2 messenger RNA. Cell 12: 1-8.

Cooper M, Johnston LH, Beggs JD. 1995. Identification and characterization of Uss1p (Sdb23p): a novel U6 snRNA-associated protein with significant similarity to core proteins of small nuclear ribonucleoproteins. EMBO J 14: 2066-2075.

Deutsch EW, Mendoza L, Shteynberg D, Farrah T, Lam H, Tasman N, Sun Z, Nilsson E, Pratt B, Prazen B, et al. 2010. A guided tour of the trans-proteomic pipeline. Proteomics 10: 1150-1159.

Dunn EA. 2014. "Investigation of free U6 small nuclear ribonucleoprotein structure and function." Ph.D. thesis, University of British Columbia, Vancouver.

Dunn EA, Rader SD. 2014. Preparation of yeast whole cell splicing extract. Methods Mol Biol 1126: 123-135.

Edgar RC. 2004. MUSCLE: multiple sequence alignment with high accuracy and high throughput. Nucleic Acids Res 32: 1792-1797.

Fischer S, Benz J, Späth B, Maier L-K, Straub J, Granzow M, Raabe M, Urlaub H, Hoffmann J, Brutschy B, et al. 2010. The archaeal Lsm protein binds to small RNAs. J Biol Chem 285: 34429-34438.

Franks TM, Lykke-Andersen J. 2008. The control of mRNA decapping and P-body formation. Mol Cell 32: 605-615.

Fromm SA, Truffault V, Kamenz J, Braun JE, Hoffmann NA, Izaurralde E, Sprangers R. 2012. The structural basis of Edc3- and Scd6-mediated activation of the Dcp1:Dcp2 mRNA decapping complex. EMBO J 31: 279-290.
Gingras A-C, Gstaiger M, Raught B, Aebersold R. 2007. Analysis of protein complexes using mass spectrometry. Nat Rev Mol Cell Biol 8: 645-654.

Guindon S, Dufayard J-F, Lefort V, Anisimova M, Hordijk W, Gascuel O. 2010. New algorithms and methods to estimate maximum-likelihood phylogenies: assessing the performance of PhyML 3.0. Syst Biol 59: 307-321.

Harlow E, Lane D. 1988. Antibodies. Cold Spring Harbor Laboratory, NY.

Horowitz DS, Kobayashi R, Krainer AR. 1997. A new cyclophilin and the human homologues of yeast Prp3 and Prp4 form a complex associated with U4/U6 snRNPs. RNA 3: 1374-1387.

Karaduman R, Fabrizio P, Hartmuth K, Urlaub H, Lührmann R. 2006. RNA structure and RNA-protein interactions in purified yeast U6 snRNPs. J Mol Biol 356: 1248-1262.

Karaduman R, Dube P, Stark H, Fabrizio P, Kastner B, Lührmann R. 2008. Structure of yeast U6 snRNPs: arrangement of Prp24p and the LSm complex as revealed by electron microscopy. RNA 14: $2528-2537$.

King DS, Beggs JD. 1990. Interactions of PRP2 protein with pre-mRNA splicing complexes in Saccharomyces cerevisiae. Nucleic Acids Res 18: 6559-6564.

Koodathingal P, Staley JP. 2013. Splicing fidelity: DEAD/H-box ATPases as molecular clocks. RNA Biol 10: 1073-1079.

Koodathingal P, Novak T, Piccirilli JA, Staley JP. 2010. The DEAH box ATPases Prp16 and Prp43 cooperate to proofread 5' splice site cleavage during pre-mRNA splicing. Mol Cell 39: 385-395.

Lerner MR, Steitz JA. 1979. Antibodies to small nuclear RNAs complexed with proteins are produced by patients with systemic lupus erythematosus. Proc Natl Acad Sci 76: 5495-5499.

Li W, Cowley A, Uludag M, Gur T, McWilliam H, Squizzato S, Park YM, Buso N, Lopez R. 2015. The EMBL-EBI bioinformatics web and programmatic tools framework. Nucleic Acids Res 43: W580-W584.

Licht K, Medenbach J, Lührmann R, Kambach C, Bindereif A. 2008. 3'cyclic phosphorylation of U6 snRNA leads to recruitment of recycling factor p110 through LSm proteins. RNA 14: 1532-1538.

Liu Q, Liang X-H, Uliel S, Belahcen M, Unger R, Michaeli S. 2004. Identification and functional characterization of Lsm proteins in Trypanosoma brucei. J Biol Chem 279: 18210-18219.

Marnef A, Weil D, Standart N. 2012. RNA-related nuclear functions of human Patlb, the P-body mRNA decay factor. Mol Biol Cell 23: 213-224.

Matsuzaki M, Misumi O, Shin-I T, Maruyama S, Takahara M, Miyagishima S-Y, Mori T, Nishida K, Yagisawa F, Nishida K, et al. 2004. Genome sequence of the ultrasmall unicellular red alga Cyanidioschyzon merolae 10D. Nature 428: 653-657.

Mayas RM, Maita H, Semlow DR, Staley JP. 2010. Spliceosome discards intermediates via the DEAH box ATPase Prp43p. Proc Natl Acad Sci 107: $10020-10025$.

Mayes AE, Verdone L, Legrain P, Beggs JD. 1999. Characterization of Sm-like proteins in yeast and their association with U6 snRNA. EMBO J 18: 4321-4331.

Muppavarapu M, Huch S, Nissan T. 2016. The cytoplasmic mRNA degradation factor Patl is required for rRNA processing. RNA Biol 13: 455-465.

Oeffinger M, Wei KE, Rogers R, DeGrasse JA, Chait BT, Aitchison JD, Rout MP. 2007. Comprehensive analysis of diverse ribonucleoprotein complexes. Nat Methods 4: 951-956.

Palfi Z, Lücke S, Lahm HW, Lane WS, Kruft V, Bragado-Nilsson E, Séraphin B, Bindereif A. 2000. The spliceosomal snRNP core complex of Trypanosoma brucei: cloning and functional analysis reveals seven Sm protein constituents. Proc Natl Acad Sci 97: 8967-8972.

Reijns MAM, Auchynnikava T, Beggs JD. 2009. Analysis of Lsm1p and Lsm8p domains in the cellular localization of Lsm complexes in budding yeast. FEBS J 276: 3602-3617.

Salgado-Garrido J, Bragado-Nilsson E, Kandels-Lewis S, Séraphin B. 1999. Sm and Sm-like proteins assemble in two related complexes of deep evolutionary origin. EMBO J 18: 3451-3462. 
Scheich C, Kümmel D, Soumailakakis D, Heinemann U, Büssow K. 2007. Vectors for co-expression of an unrestricted number of proteins. Nucleic Acids Res 35: e43.

Séraphin B. 1995. Sm and Sm-like proteins belong to a large family: identification of proteins of the U6 as well as the U1, U2, U4 and U5 snRNPs. EMBO J 14: 2089-2098.

Sharif H, Conti E. 2013. Architecture of the Lsm1-7-Pat1 complex: a conserved assembly in eukaryotic mRNA turnover. Cell Rep 5: 283-291.

Shteynberg D, Deutsch EW, Lam H, Eng JK, Sun Z, Tasman N, Mendoza L, Moritz RL, Aebersold R, Nesvizhskii AI. 2011. iProphet: multi-level integrative analysis of shotgun proteomic data improves peptide and protein identification rates and error estimates. Mol Cell Proteomics 10: M111.007690.

Stark MR, Dunn EA, Dunn WSC, Grisdale CJ, Daniele AR, Halstead MRG, Fast NM, Rader SD. 2015. Dramatically reduced spliceosome in Cyanidioschyzon merolae. Proc Natl Acad Sci 112: E1191-E200.

Studier FW. 2005. Protein production by auto-induction in high density shaking cultures. Protein Expr Purif 41: 207-234.

Suzuki K, Ehara T, Osafune T, Kuroiwa H, Kawano S, Kuroiwa T. 1994. Behavior of mitochondria, chloroplasts and their nuclei during the mitotic cycle in the ultramicroalga Cyanidioschyzon merolae. Eur J Cell Biol 63: 280-288.

Tang W, Kannan R, Blanchette M, Baumann P. 2012. Telomerase RNA biogenesis involves sequential binding by $\mathrm{Sm}$ and Lsm complexes. Nature 484: 260-264.

Tharun S, He W, Mayes AE, Lennertz P, Beggs JD, Parker R. 2000. Yeast Sm-like proteins function in mRNA decapping and decay. Nature 404: 515-518.

Tkacz ID, Cohen S, Salmon-Divon M, Michaeli S. 2008. Identification of the heptameric Lsm complex that binds U6 snRNA in Trypanosoma brucei. Mol Biochem Parasitol 160: 22-31.

Tkacz ID, Gupta SK, Volkov V, Romano M, Haham T, Tulinski P, Lebenthal I, Michaeli S. 2010. Analysis of spliceosomal proteins in Trypanosomatids reveals novel functions in mRNA processing. J Biol Chem 285: 27982-27999.
Tomasevic N, Peculis BA. 2002. Xenopus LSm proteins bind U8 snoRNA via an internal evolutionarily conserved octamer sequence. Mol Cell Biol 22: 4101-4112.

Trahan C, Aguilar L-C, Oeffinger M. 2016. Single-step affinity purification (ssAP) and mass spectrometry of macromolecular complexes in the yeast S. cerevisiae. Methods Mol Biol 1361: 265-287.

Vidal VP, Verdone L, Mayes AE, Beggs JD. 1999. Characterization of U6 snRNA-protein interactions. RNA 5: 1470-1481.

Wahl MC, Will CL, Lührmann R. 2009. The spliceosome: design principles of a dynamic RNP machine. Cell 136: 701-718.

Wang X, Watt PM, Louis EJ, Borts RH, Hickson ID. 1996. Pat1: a topoisomerase II-associated protein required for faithful chromosome transmission in Saccharomyces cerevisiae. Nucleic Acids Res 24: 4791-4797.

Ward N, Moreno-Hagelsieb G. 2014. Quickly finding orthologs as reciprocal best hits with BLAT, LAST, and UBLAST: how much do we miss? PLoS One 9: e101850.

Wilusz CJ, Wilusz J. 2013. Lsm proteins and Hfq: life at the $3^{\prime}$ end. RNA Biol 10: 592-601.

Wu S, Zhang Y. 2007. LOMETS: a local meta-threading-server for protein structure prediction. Nucleic Acids Res 35: 3375-3382.

Wu D, Muhlrad D, Bowler MW, Jiang S, Liu Z, Parker R, Song H. 2014. Lsm 2 and Lsm3 bridge the interaction of the Lsm1-7 complex with Patl for decapping activation. Cell Res 24: 233-246.

Yagisawa F, Nishida K, Kuroiwa H, Nagata T, Kuroiwa T. 2007. Identification and mitotic partitioning strategies of vacuoles in the unicellular red alga Cyanidioschyzon merolae. Planta 226: 1017-1029.

Zaric B, Chami M, Rémigy H, Engel A, Ballmer-Hofer K, Winkler FK, Kambach C. 2005. Reconstitution of two recombinant LSm protein complexes reveals aspects of their architecture, assembly, and function. J Biol Chem 280: 16066-16075.

Zhou L, Hang J, Zhou Y, Wan R, Lu G, Yin P, Yan C, Shi Y. 2014. Crystal structures of the Lsm complex bound to the $3^{\prime}$ end sequence of U6 small nuclear RNA. Nature 506: 116-120. 

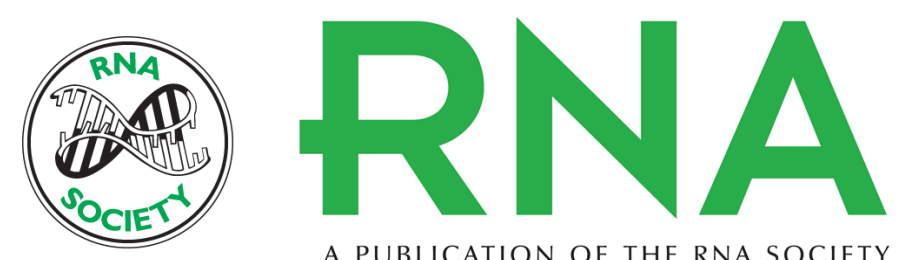

A PUBLICATION OF THE RNA SOCIETY

\section{The sole LSm complex in Cyanidioschyzon merolae associates with pre-mRNA splicing and mRNA degradation factors}

Kirsten A. Reimer, Martha R. Stark, Lisbeth-Carolina Aguilar, et al.

RNA 2017 23: 952-967 originally published online March 21, 2017

Access the most recent version at doi:10.1261/rna.058487.116

\section{Supplemental http://rnajournal.cshlp.org/content/suppl/2017/03/21/rna.058487.116.DC1 \\ Material}

References This article cites 63 articles, 22 of which can be accessed free at: http://rnajournal.cshlp.org/content/23/6/952.full.html\#ref-list-1

Creative This article is distributed exclusively by the RNA Society for the first 12 months after the Commons

License full-issue publication date (see http://rnajournal.cshlp.org/site/misc/terms.xhtml). After 12 months, it is available under a Creative Commons License (Attribution-NonCommercial 4.0 International), as described at http://creativecommons.org/licenses/by-nc/4.0/.

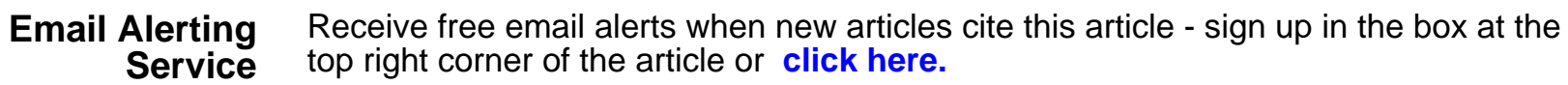

